Año LI. urtea

$127-2019$

Urtarrila-ekaina

Enero-junio

5

รar.

ats

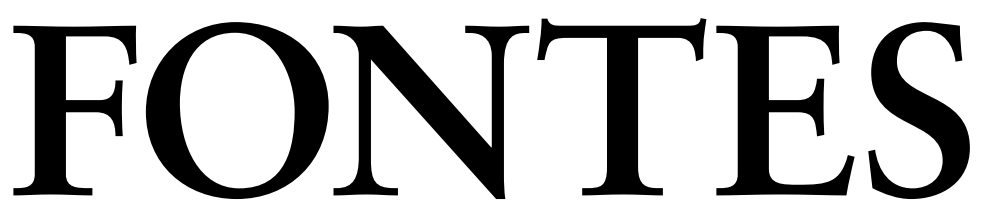

LINGVÆ

VASCONVM

STVDIA ET DOCVMENTA

SEPARATA

\title{
Erlazio-atzizkia eta \\ hitz-ordenaren aldaketa
}

Dorota KRAJEwSKa

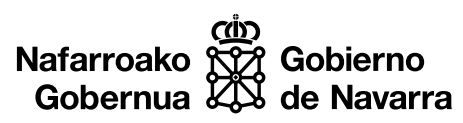

- 00 


\title{
Erlazio-atzizkia eta hitz-ordenaren aldaketa
}

\author{
El sufijo relacional vasco y el cambio de orden de palabras
}

Basque relational marker and word order change

Dorota KRAJEWSKA

Euskal Herriko Unibertsitatea (UPV/EHU)

dorota.krajewska@ehu.eus

Ikerketa hau «Lingüística histórica e historia de la lengua vasca» [GIC10/83, IT486-10] ikerketa-talde iraunkorraren (EJ) eta «Monumenta Linguae Vasconum V» [FFI2016-76032-P] proiektuaren (MINECO) barnean gauzatu da.

Jasotze data: 2018/03/12. Behin-behineko onartze data: 2018/05/30. Behin betiko onartze data: 2018/07/03. 


\section{LABURPENA}

Lan honetan - $k o$ erlazio-atzizkia duten sintagmen kokapena (izenaren aurrekoa eta izenaren ostekoa) aztertzen da ikuspuntu diakronikotik. Atzizkiaren funtzioa izenen modifikatzaileak sortzea da, adberbioetatik, leku kasua, instrumentala edo postposizioa duten izenetatik eta izen-multzoetatik. Helburua da hitz-ordenaren bariazioa deskribatzea eta erabileran eragina zuten faktoreak identifikatzea. Proposatzen da izen osteko - $k o$ modifikatzaileak sortu zirela erlazio-atzizkia zuten sintagma batzuk adjektibo bezala lexikalizatu zirelako, eta adjektiboari zegokion kokapenean hasi zirela jartzen, hau da, izenaren eskuinean.

Gako hitzak: hitz-ordena; morfologia; diakronia; -ko atzizkia.

\section{RESUMEN}

En el presente trabajo se analiza la posición de los sintagmas que contienen el sufijo de relación - $k o$ (pronominal o postnominal) desde un punto de vista diacrónico. Mediante dicho sufijo se crean modificadores adjetivales a partir de adverbios, sintagmas nominales o sustantivos dotados con casos locativos, instrumentales o posposiciones. El objeto del trabajo es describir la variación existente en el orden de las palabras e identificar los factores que influyen en el uso de unas u otras variantes. Se propone que los modificadores con - $k o$ postnominal fueron creados tras la lexicalización como adjetivos de algunos sintagmas dotados del sufijo relacional; en concreto, su posición sintáctica cambió a la del adjetivo, pasando de ser pronominales a postnominales.

Palabras clave: orden de palabras; morfología; diacronía; sufijo - $k o$.

\section{ABSTRACT}

This paper deals with the relational marker $-k o$, which derives adjectival modifiers from a wide range of phrases: adverbs, local-case- or instrumental-marked nouns, postpositions and determinerless NPs. More specifically, the goal is to describe the constituent order variation from a diachronic perspective. There are two options: the modifier might be prenominal (default in the modern language) or postnominal. My proposal is that postnominal - $k o$ modifiers appeared because some - $k$ o phrases lexicalized as adjectives and started to be placed after the noun, in the position where canonical qualitative adjectives go in Basque.

Keywords: word-order; morphology; diachrony; the suffix -ko. 
1. SARRERA. 2. IZEN-MODIFIKAZIOA: JABETZAREN ETA ADJEKTIBOEN ARTEAN. 2.1. Aingura- eta aingura gabeko erlazioak. 2.2. Jabetza-modifikazio eskala. 2.3. Euskarak erabiltzen dituen baliabideak. 3. CORPUSAREN AZTERKETA. 3.1. Atarikoak. 3.2. Aingura- eta aingura gabeko erlazioak testuetan. 3.3. Testuen azterketa. 3.3.1. Erdi Aroa. 3.3.2. Etxepare. 3.3.3. Leizarraga. 3.3.4. Araba. 3.3.5. Bizkaia. 3.3.6. Gipuzkoa. 3.3.7. Lapurdi. 3.3.8. Nafarroa Garaia. 3.3.9. Zuberoa. 3.3.10. Erronkaribar. 3.4. Orokortuz. 4. ONDORIOAK. 5. ERREFERENTZIAK.

\section{SARRERA}

Euskal gramatikariei arazoak ematen zizkien luzaroan -ko atzizkiak -«hizkuntzaren atzizki inportanteenetarik bat» (Trask, 1985, 165. orr.)-, agian ondoko hizkuntzetan antzeko baliabiderik ez dagoelako, eta luzaroan latin-erromantzearen kategoriak izan direlako euskara deskribatzeko eredu.

Trasken arabera, atzizkiaren erabilera nagusian adberbio-funtzioa duen (ia) edozein sintagmak, sinpleak ala konplexuak, -ko atzizkia har dezake izenaren modifikatzailea sortzeko, eta atzizkiak funtzio sintaktikoa betetzen duela esan daiteke. Goenagak (1981) plazaratu zuen ideia hori lehenbiziko aldiz. Traskek (1984, 195. orr.) uste zuen inor ez zela lehenago horretaz jabetu, etxeko erako segidak, azalean kasu-atzizkirik ez dutenak, askoz ere maizago erabiltzen direlako beste aukera guztiak baino.

Hala ere, oinarri adberbiala duten sintagmez gain, bestelako erabilera batzuk ere baditugu. Izen-multzoari ere eransten zaio atzizkia, hitz gutxiko edo bihotz oneko bezalako modifikatzaileak sortuz. Gainera, atzizkia ez da beti erabiltzen izenen modifikatzaileak eratortzeko: izenak ere sortzen ditu (lekuko, belarritako...; Azkarate, 1990). Azkenik, batez ere testu zaharretan agertzen den destinatibozko esanahia duen -ko atzizkia dugu (adibidez, $R S$-ko Guibeleco on dana areco gasso).

Atzizkiaren hainbat ezaugarri-adibidez, gaurko hizkuntzan dituen funtzioak-ikertu badira ere (Goenaga, 1981; Trask, 1984, 1985; Azkarate \& Altuna, 1992; De Rijk, 1993, 2008; Zabala, 1999), aztertu ez den gai bat da atzizkia duen modifikatzailearen eta izenaren arteko hitz-ordena: izen aurrekoa (IAkoa) ala izen ostekoa (IOkoa) den. 
Nahiz eta izen osteko - $k$ o sintagmak aipatzen diren lan batzuetan (adibidez, Lafon, 1999 [1965]; Goenaga, 1985; Odriozola \& Cantero, 1992; Eguzkitza, 1993; Lakarra, 2005; de Rijk, 2008; Martínez-Areta, 2011; Reguero, 2013), erabilera horren inguruan zehaztasun gutxi aurki daiteke (aipatu diren ideiak 3.1 atalean laburbilduko ditut).

Gaur egun, izenaren ezkerrean jartzen dira -ko sintagmak, izenlagun guztiak ${ }^{1}$-perpaus erlatiboak edo genitiboak- bezala (Trask, 2003, 148. orr.). Testu zaharretan, hala ere, kontrako hurrenkeraren adibideak aurki daitezke. Lan honetan horiek aztertuko ditut, hain zuzen, testu zaharrenetatik hasi eta XIX. mendera arte. Helburu nagusia da, bariazio hori deskribatzeaz gain, aldaketen arrazoia antzematea. Proposamen nagusia da - $k o$ atzizkia duten modifikatzaile batzuk adjektibo bihurtu edo behintzat bihurtzen hasi zirela eta horrek eragin zuen hitz-ordenaren aldaketa, adjektiboei dagokien tokian hasi zirelako jartzen - $k o$ sintagmak.

Lanaren egitura honakoa da: sarrera hau amaitzeko lan honetan aztertu dudan corpusa deskribatuko dut. 2. atalean, - $k o$ atzizkiari eta horrekin lotutako baliabideei ikuspuntu tipologikotik begiratuko diet eta nire azalpenetarako beharrezkoak diren kontzeptuak azalduko ditut. 3. atalean, atzizkiaren jokaera azaltzeko proposamena zehaztuko dut eta lekukotasunak aztertuko ditut. 4. atalak lanaren ondorioak biltzen ditu.

Hitz-ordena aztertzeko corpus hau erabili dut, nahiz eta hainbatetan testu gehiago -batez ere testu zaharrak- ere aipatu:

a) Bizkaia: RS - Refranes y sentencias (Lakarra, 1996); VJ - Viva Jesus (Ulibarri Orueta, 2010); Kap - Kapanaga, Dotrinea, 1656 (K. Ulibarriren transkripzioa); Arz - Arzadun, Doktrina kristianeen explikazinoa, $1731(\mathrm{KG})^{2}$; Olaetx - Olaetxea, Dotrina Kristianea, 1763 (KG); Mogel - Mogel, Peru Abarka, 1802 (KG; 1-3. elkarrizketak); frBart - frai Bartolome, Euskal Errijetako olgeeta ta dantzeen neurrizko gatz-ozpinduba, 1816 (KG; 1. eta 2. kapituluak, eta 3.etik $\$ 1$ eta $\$ 2$ ).

b) Araba: Land - Landucci (Mitxelena, 2011 [1958]); Laz - Lazarraga, Artzainliburua (Bilbao et al., 2010); Bet - Betolatza, Doktrina Kristiana (KG).

c) Gipuzkoa: OA - Otxoa Arin, Doktrina kristianaren explikazioa, 1713 (KG; VII. kapituluraino); Ubill - Ubillos, Kristau berri-ekarlea, 1785 (KG; XII. kapituluraino); Gerriko - Gerriko, Kristau doktriña guztiaren esplikazioaren saiakera, 1805 (KG; 1. eta 2. dotrinak).

d) Lapurdi: LeizMat - Leizarraga, San Mateo (KG); LeizABC - Leizarraga, $A B C$ (KG); LeizSarrera - Leizarraga, Testamentuaren paratestuak: Joana Albretekoari

1 Lan honetan ez dut izenlagun izendapena erabiliko, bere definizioan hitz-ordenari egiten baitzaio erreferentzia normalean (adibidez, «izenaren ezkerrean jarri ohi ditugun adjektiboak, - $k o$ eta -en atzizkien bidez osatuak»; Euskara Institutua, d.g.). Adjektibo terminoa izenondoez hitz egiteko erabiliko dut.

2 KG: Klasikoen Gordailu-tik hartutako testuak. 
eskaintza eta Heuskaldunei (KG); Mat - Materra, Dotrina Christiana, 1623 (Krajewska et al., 2017); Haranb - Haranburu, Debozino eskuarra, 1635 (KG; «Kofesioko mirailla» deitzen den ataleraino); Harand - Haraneder, Jesu Kristoren ebanjelio saindua (San Mateo), 1740 (KG); Duh - Duhalde, Meditazioneak gei premiatsuenen gainean, 1809 (KG; «Jesusen izen seinduaren letaniak» atala arte).

e) Zuberoa: Tartas - Tartas, Onsa hilzeko bidia, 1666 (KG; 1. eta 2. kapituluak); Belap - Belapeire, Katexima labürra, 1696 (KG; 20. kapitulua arte); Oloroe Oloroeko katixima, 1706 (Padilla-Moyano, prestatzen); Mst - Maister, Jesü-Kristen imitazionia, 1757 (KG; 1. liburua eta 3.aren 1-6. kap.).

f) Nafarroa Garaia: Ber - Beriain, Tratazen da nola enzun bear den meza, 1621 (KG), Elizalde - Elizalde, Apezendako dotrina kristiana uskaraz, 1735 (KG), Lizarg - Lizarraga, Zenbait sanduen biziak asteaz datozinak, 1793 (KG; lehen 15 sainduak).

g) Erronkaribar: Ros - Miguel Rosen gutunak (Bilbao et al., prestatzen), DokrtErr Doctrina Christiaia (Pagola et al., 1997), Hualde - Hualde Mayo, San Mateoren Ebanjelioa, 1855 (Pagola et al., 1997).

h) Nafarroa Beherea: Etx - Etxepare, Linguae Vasconum Primitiae (KG, Altuna, 1980).

\section{IZEN-MODIFIKAZIOA: JABETZAREN ETA ADJEKTIBOEN ARTEAN}

Datu historikoak aztertzen hasi baino lehen, - $k o$ atzizkia testuinguru zabalagoan kokatzeko, izen-modifikazioaren kontzeptuaz modu orokorragoan hitz egingo dut. Erlazio-atzizkiaren erabileraren hainbat alderdi, hitz-ordenaren gorabeherak, esaterako, ulertzeko lagungarria izango da.

Erlazio-atzizkiak sortzen dituen modifikatzaileen papera ez da beti berdina: harrizko etxea (materiala zehazten du), Gasteizko alde zaharra (tokia), datorren asteko afaria (denbora zehatza), udako oporrak (denbora, baina ez definitua, 'opor-mota bat'). Diferentzia horiek, dudarik gabe atzizkia lotzen zaion jatorrizko elementuaren semantikarekin lotuta, eragina dute - $k o$ duten sintagmen jokaeran. Horregatik, -ko atzizkiaren funtzioak hobeto deskribatzeko, aingura-erlazioen eta aingura gabeko erlazioen kontzeptua (Koptjevskaja-Tamm, 2002, 2004) erabilgarria da.

Bestalde, inportantea da - $k o$ alderatzea izenen beste modifikatzaile batzuekin, eta bereziki genitiboarekin eta adjektiboekin. Horretarako, jabetza-modifikazio eskala (Nikolaeva \& Spencer, 2010) erabiliko dut. Ikusiko denez, -ko sintagmak genitibo eta adjektiboen artean geratzen dira, eta - $k o$ sintagmen portaerak islatzen du hori: esaterako, adjektibo bihurtzea edo adjektiboen ezaugarri batzuk hartzea azaltzen du, bai eta genitiboarekiko lehian sartzea ere. Artikulu honetan adjektiboekiko erlazioetan zentratuko naiz. 


\subsection{Aingura- eta aingura gabeko erlazioak}

Aingura- eta aingura gabeko erlazioak bereizteko Koptjevskaja-Tamm-en (2002, 2004) lanetan oinarrituko naiz. Bere abiapuntua jabetza-erlazioa adierazten duten egiturak dira. Euskarazko - $k o$ atzizkiak, noski, ez du jabetza prototipikoa inoiz markatzen (jabetza prototipikoa John's book sintagman adierazten dena da: jabe bizidun eta definitu batekin). Hala ere, beste hizkuntza askotan jabetza prototipikoaren esanahia duten egiturek - $k o$ atzizkiaren funtzio batzuk ere betetzen dituzte.

Egitura posesiboek adierazten dituzten esanahiak deskribatzea ez da batere erraza. Koptjevskaja-Tammek (2002, 142. orr.) dioen bezala, "what makes linguistic possession so elusive and difficult to define and explain is the variety of meanings attributed to or relations expressed by one and the same construction type». Adibiderik sinpleena -John's book- aztertzen hasita ere, John-en eta liburuaren arteko erlazioa modu askotan uler daitekeela konturatzen gara:

In cultures that have an institution of legal ownership this expression will often be paraphrasable as something like 'book which John owns'. However, this is by no means the only possible interpretation. It can also refer to the book that John wrote, the book that he stole, the book he always talks about, the book he wants to buy or the book that he has just been given to review as a class assignment. The possessive relation here is not narrowly determined on the basis of inherent semantic properties of the possessed noun and, consequently, allows for various readings (Nikolaeva \& Spencer, 2010, 5. orr.).

Koptjevskaja-Tammen arabera, egitura posesiboen erabilera gehien-gehienetan, bi objektu jartzen dira erlazioan, eta modifikatzailearen bidez sintagmaren ardatza definitzen edo ezaugarritzen da. Egitura posesiboek adierazten dituzten erlazioak bi multzotan sailka daitezke: batetik, aingura-erlazioak ditugu (A, anchoring relations) eta, bestalde, aingura gabeko erlazioak (AG, non-anchoring).

Aingura-erlazioak direla eta, jabetza prototipikoaz gain, honako hauek dira ohikoak: gorputzaren atalak (girl's hand, neskaren eskua), familia-erlazioak (kinship relations delakoak: John's wife, Jonen emaztea), autoretza (John's poem, Jonen poema), gizarteharremanak (John's friend, Jonen laguna), partea (mountain's top, mendi gaina), denbora (Monday's performance, asteleheneko emanaldia) edo lekua (Stockholm's parks, Stockholmeko parkeak). Koptjevskaja-Tammen (2002) arabera, erabilera horietan modifikatzaileak ardatzaren erreferentzia identifikatzeko zantzua ematen du, eta, hortaz, «ainguraren» edo erreferentzia-puntuaren funtzioa du. Bai ardatza eta bai modifikatzailea erreferentzialak izaten dira, eta aingura onenak zehatzak, bizidunak eta definituak dira, erraz identifikatzen baitira.

Bestalde, aingura gabeko erlazioak ditugu. Koptjevskaja-Tammen arabera, kasu horretan modifikatzailearen funtzioa ez da hainbeste ardatzaren erreferentea identifikatzen laguntzea, hura sailkatzea, deskribatzea edo ezaugarritzea baizik. Bi erlazioen arteko alde hori ez da beti formalki markatzen, eta hizkuntza askotan egitura berberak 
erabiltzen dira biak adierazteko. Aingura gabeko erlazioetan modifikatzailea ez da erreferentziala; hau da, ez dio objektu jakin bati erreferentzia egiten, ez du diskurtsoan erreferente berri bat sartzen, eta anaforaren aurrekaria ezin da izan. Adibidez, materiala adierazten denean (a golden ring, urrezko eraztuna), modifikatzaileak (golden, urrezko) ez du objektu zehatz bat seinalatzen, ezaugarri batzuk baizik (KoptjevskajaTamm, 2004, 158. orr.). Horregatik aingura gabeko modifikatzaileek ez dute definitumarkarik (erakusleak, artikuluak, etab.) hartzen. Gaztelaniaz, esaterako: la casa del profesor dugu, baina la casa de piedra. Bestalde, normalean, aingura-modifikatzaileak ardatzetik urrunago joaten dira (mother's golden ring).

Koptjevskaja-Tammek (2002, 154. orr.) dioenez, aingura-erlazioen mota eta azpimota guztiak ondo zehaztea latza bada, «things get even worse when we leave the anchoring functions of possessors and move on to non-anchoring ones». Nolanahi ere, erlazio tipikoak honako hauek izaten dira:

a) materiala: a golden ring, urrezko eraztuna

b) iraupena: a journey of one month, hilabete bateko bidaia

c) adina: a girl of 17 years, 17 urteko neska

d) neurria edo kopurua: a ship of a thousand tons, mila tonako ontzia

e) xedea: a bread knife, a coffee cup, ogi-labana, kafe-katilua

f) ezaugarria/nolakotasuna: man of low statue, altuera gutxiko gizona

g) antzekotasuna: eagle's eyes, arrano begiak ('begi zorrotzak')

h) denbora eta lekua (generikoak): mountain tree, summer weather, mendiko zuhaitza, udako eguraldia

i) zerbait norentzat egina den: a women's magazine, emakumeentzako aldizkaria.

\subsection{Jabetza-modifikazio eskala}

Ohikoa da aingura gabeko modifikatzaileek izen bezala autonomia galtzea. Horrela, [izena modifikatzailea] egitura izen elkartu bihur daiteke, edo modifikatzailea adjektibo bihurtu, edo adjektiboen ezaugarri batzuk hartu behintzat. Oro har, izenen modifikatzaile bezala erabiltzen diren izenak hauen eta adjektiboen artean daude. Jarraian ideia horri helduko diot, jabetza-modifikazio (possession-modification scale) eskala deskribatuz.

Eskala hori Nikolaevak \& Spencerrek (2010) proposatu dute, eta honako puntu hauek bereizi dituzte: 
(1) (A) jabetza utziezina (inalienable possession) > (B) jabetza (alienable possession) > (C) izen-modifikazioa (modification-by-noun edo nominal modification) > (D) adjektiboak

Lehenengo biak jabetzari dagozkio, eta azken biak modifikazioari. Eskalaren antolamendua lotuta dago egituren semantikarekin, baina baita hizkuntzek horiek adierazteko erabiltzen dituzten baliabideekin ere.

Jabetza dela eta ${ }^{3}$, egitura posesiboen erabilera prototipikoa dugu: «exclusive asymmetric long-term relation and physical proximity between two entities, for each possessee there is only one possessor who has the right to make use of the possessee, and the possessor is normally an individuated human being» (Nikolaeva \& Spencer, 2010, 6. orr.). Hala ere, aurreko atalean azaldu bezala, jabetza prototipikoaz gain, beste aingura-erlazio batzuk ere adieraz ditzakete egitura posesiboek.

Izen-modifikazioan izena beste izen batekin erlazioan jartzen da. Hizkuntza guztietan posible da hori egitea, baina baliabideak aldatzen dira. Hizkuntza germanikoetan, esaterako, I-I konposizio endozentrikoa oso arrunta da (coffee cup). Esanahiari dagokionez, pragmatikaren araberakoa da:

For example, for the newly created non-lexicalized compound pea princess the following interpretations were suggested among others by the native speakers (Downing, 1977, 820. orr.): 'a fairy princess who rules the pea people', 'the fairytale princess who felt the pea under her mattresses', 'the princess of the Pea kingdom', 'the princess shaped like a pea or with the colour of a pea', 'a princess whose family is rich with pea farms', and so on. There is nothing in the meaning of the compounding construction that can explain this (Nikolaeva \& Spencer, 2010, 9. orr.).

Aingura gabeko erlazioak adierazten dira izen-modifikazioan: klase bati egiten zaio erreferentzia, ez objektu jakin bati; gainera, modifikatzaileak eta ardatzak batera adierazten dute kontzeptu bat ( $\operatorname{dog}$ collar = lepoko-mota bat). Hori sintaxian islatzen da askotan: jabeak determinatuak izaten dira; izen-modifikazioan, aldiz, normalean determinatu gabeak (izenak soilik edo izen-multzoak dira).

Eskalaren azken puntuan adjektiboak daude. Adjektibo prototipikoak mailakatzen dira eta ezaugarri bat adierazten dute. Argumentu bateko predikatuak dira; izen-modifikazioan, aldiz, bi izen harremanetan jartzen dira.

Lau kategoria horiek gauzatzeko baliabideei dagokienez, Nikolaevak eta Spencerrek (2010) ondorioztatu dute, salbuespenak salbuespen, hizkuntzek eskalari jarraitzen diotela: bi puntu berdin markatzen badira, tartean dagoena ere modu berean adierazten da (adibidez: $\mathrm{A}=\mathrm{B}=\mathrm{C} \neq \mathrm{D}$ konfigurazioa orokortzearekin bat dator, baina ez $\mathrm{A}=\mathrm{C} \neq \mathrm{B}$ = D). Jabetza modu batean eta modifikazioa beste modu batean adieraztea oso arrunta

3 Jabetza utziezina ez dut deskribatuko, ez baitu zerikusirik hemen aztertzen ditudan gaiekin. 
da egile horien arabera, bereziki naturala delako (erreferentzialtasunak banatzen ditu), baina bestelako konfigurazioak ere ez dira falta munduko hizkuntzetan.

Jabetza, izen-modifikazioa eta adjektiboak ezberdinak izanik ere, ezaugarri komun batzuk ere badituzte. Nikolaevaren eta Spencerren arabera, jabetzan eta izen-modifikazioan testuinguruak edo pragmatikak determinatzen du ardatzaren eta modifikatzailearen arteko erlazioa. Bien arteko aldea adierazten diren erlazio-motak dira: ainguraerlazioak jabetzan eta aingura gabekoak bestean. Izen-modifikazioan eta adjektibo kanonikoetan, aldiz, bi multzoen ebaketa adierazten da. Adjektiboei dagokienez, kasurik arruntenean, etxe handia sintagman adjektiboak etxeen multzoan azpi-multzo bat identifikatzen du. Izen-modifikazioa antzekoa dela esan daiteke: katu-janaria konposatuak janariaren azpi-multzo bat adierazten du, 'katu kontzeptuarekin nolabaiteko harremana duen janaria', hain zuzen (harreman horren izaera zehatza, azaldu bezala, pragmatikaren mende dago). Bi modifikazio-mota horien arteko aldea da adjektibo kanonikoek ezaugarri sinpleak adierazten dituztela eta izen-modifikazioan konplexuak, izate bat baino gehiago dagoelako tartean.

Lan honetan eskala horren inplikazio diakronikoek garrantzia izango dute: baliabide morfologikoen erabilera alda daiteke denborarekin eta eskalan ondoan daudenetara zabaldu. Adibidez, bien arteko antzekotasunak direla eta, izenen modifikatzaileek adjektiboen ezaugarri batzuk har ditzakete. Erlazio-atzizkiari dagokionez, saiatuko naiz erakusten $-k o$ atzizkiarekin jazo den hitz-ordenaren aldaketa gertatu dela hizki hori duten modifikatzaileek adjektiboen ezaugarri batzuk hartu dituztelako ${ }^{4}$.

\subsection{Euskarak erabiltzen dituen baliabideak}

Munduko hizkuntzetan ohikoa da egitura bat baino gehiago erabiltzea jabetza-modifikazioa erlazioak adierazteko, baita erlazio-mota batean egitura batzuk lehian egotea ere. Ingelesez, bi genitibo, konposizioa eta adjektiboak ditugu (1. taula). Beste adibide bat latina da. Latinez genitiboa beste hainbat egiturarekin lehiatzen zen: jabetza-genitiboa adjektiboekin, definizio-genitiboa egitura aposatuekin, nolakotasun-genitiboa bahuvrihi konposatuekin eta nolakotasun-ablatiboarekin (Kuryłowicz, 1964).

Euskaraz (2. taula) ere baliabide batzuk baditugu: genitiboa, I-I konposizioa, $-k o$ atzizkia eta adjektiboa dira garrantzitsuenak. Aurrekoei -dun atzizkia eta I-Adj konposatuak ere gehitu behar zaizkie. Aingura-erlazioak adierazteko, genitiboa eta erlazio-atzizkia erabiltzen dira, baina aingura gabeko erlazioetan aukera gehiago ditugu. Erlazio-atzizkiaren berezitasuna da, beraz, erlazio ezberdinak adierazteko balio duela ${ }^{5}$. Horrek hitz-ordenan duen eragina aztertuko dut hurrengo atalean.

4 Hemen izen-modifikaziotik adjektiboetarako aldaketan zentratuko naiz, baina eskalaren ezkerreko partea ere izan daiteke interesgarria: izan ere, -ko atzizkia genitiboarekin ere lehiatzen da, eta horregatik atzizkiaren erabilera batzuk izen-modifikaziotik jabetzarako aldaketa bezala interpreta daitezke.

5 Cfr. Lafon (1999 [1965], 177. orr.) «un déterminant pourvu de ce suffixe [-ko] peut désigner soit un objet particulier soit une classe d'objets». 
1. taula. Aingura- eta aingura gabeko erlazioak adierazteko modu ohikoenak ingelesez (Magni, 2013 lanean oinarrituta)

\begin{tabular}{|l|l|l|}
\multirow{2}{*}{ Erlazioa } & Egitura & Adibidea \\
\hline \multirow{3}{*}{ A } & 's genitiboa & John's house \\
\cline { 2 - 3 } & of genitiboa & queen of England \\
\hline & I-I konposatuak & summer holidays \\
\cline { 2 - 3 } & 's genitiboa & woman's magazine \\
\cline { 2 - 3 } & of genitiboa & man of great influence \\
\cline { 2 - 3 } & adjektiboak & blue sky \\
\hline
\end{tabular}

2. taula. Aingura- eta aingura gabeko erlazioak adierazteko modu ohikoenak euskaraz

\begin{tabular}{|l|l|l|}
\hline \multirow{2}{*}{ Erlazioa } & Egitura & Adibidea \\
\hline \multirow{4}{*}{ AG } & genitiboa & Jonen etxea \\
\cline { 2 - 3 } & -ko atzizkia & atzoko afaria \\
\hline & I-I konposatuak & talde lana \\
\cline { 2 - 3 } & $-k o$ atzizkia & $\begin{array}{l}\text { udako oporrak } \\
\text { ospe handiko gizona }\end{array}$ \\
\cline { 2 - 3 } & I-Adj konposatuak & mutil begi handia \\
\cline { 2 - 3 } & -dun & praka gorridun mutila \\
\cline { 2 - 3 } & adjektiboak & zeru urdina \\
\hline
\end{tabular}

\section{CORPUSAREN AZTERKETA}

\subsection{Atarikoak}

Atal honetan testuetan agertzen diren - $k o$ sintagmak eta izenarekiko posizioa aztertuko ditut. Proposatuko dut -ko sintagmen izen osteko erabilera sortu dela sintagma horietako batzuk adjektibo berranalizatu direlako, eta adjektiboei dagokien kokapenean hasi direlako jartzen. Ideia ez da erabat berria: Lafonek (1999 [1965], 176. orr.) adjektiboekiko analogia aipatzen du genitiboaren eta -ko-ren jokaera deskribatuz:

Les deux génitifs et les formations en -ko qui viennent d'être mentionnées s'emploient le plus souvent comme déterminant de substantif, et, dans cet emploi, se placent normalement devant le substantif qu'ils déterminent. Mais ils sont parfois placés après ce substantif, par analogie avec les adjectifs épithètes (BSL, LIX, 7-8). Or le 2 e génitif et les formations en -ko se placent beaucoup plus souvent que le ler génitif après le substantif déterminé.

Orobat, Lafonek adjektiboen eta - $k o$ sintagmen arteko lotura batzuk aipatzen ditu. Erdarazko adjektiboen ordainak dira askotan -ko sintagmak: etxeko 'de (la) maison, domestique' edo balizko 'imaginaire'. Bestalde, sudur handiko motakoek kalifikazioa adierazten dute. Azkenik, -ko sintagmak predikatu bezala erabil daitezke, adjektiboak bezala (harrizkoa da eta handia da). 
Bestalde, Odriozolak \& Canterok (1992) -ko sintagma batzuen lexikalizazioa aipatzen dute. Adibidez, egiazko moduko hitzen kasuan, hiztunak ez dira -ko atzizkiaren presentziaz ohartzen, eta handi edo luze hitzak bezala erabiltzen hasten dira. Hala ere, atzizkiaren kontzientzia galduta ere, izenaren aurretik kokatzeko aukera ez da desagertzen. Hizkuntza-ukipenak ere eragina duela esaten dute egileek. Erdarazko adjektiboen ordainak kategoria ezberdinetakoak dira euskaraz: adjektiboak, -ko sintagmak edo euskal literatura moduko hitz elkartuak. Horrek, sintagma batzuen lexikalizazioarekin batera, izenlagunen eta izenondoen artean nahasketak sor ditzake. Erlazio-atzizkiaren kasuan, Odriozola \& Canteroren (1992, 1039. orr.) iritziz, izen osteko posizioa ez da ondo onartzen «leku, denbora edo bestelako zirkunstantzia bat» adierazten duten sintagmekin ("Independentzia tenperaturarekikoa), eta onargarriagoak dira ezaugarri bat adierazten dutenak, izenondoetatik hurbilago geratzen direnak (nahitaezko, egiazko).

Beraz, badirudi izenaren eskuinean ezin dela edozein sintagma agertu. Funtsean, Odriozola \& Canteroren (1992) ideiaren ildotik, saiatuko naiz erakusten -ko sintagma bat adjektiboetatik zenbat eta hurbilago izan, orduan eta aukera gehiago dituela izenaren ostean agertzeko. Aurreko atalean azaldu bezala, izen-modifikazioaren eta adjektiboen artean badaude antzekotasun semantiko batzuk, eta horregatik ez da harrigarria kategoria batetik bestera pasatzea.

Adjektiboetatik hurbiltasun hori zehazteko, -ko sintagmak adierazten duen erlaziomota -aingura edo aingura gabekoa- izango dira inportanteak. Aingura gabeko erlazioa adierazten duten - $k o$ sintagmek izenaren ostean agertzeko joera handiagoa dute, adjektiboetatik hurbilago direlako. Aingura-funtzioa duten sintagmak, batez ere definituak direnean (erakusle batekin, adibidez), aldiz, izenaren ezkerrean doaz normalean.

Bestalde, ikusiko den moduan, -ko sintagmek gehienetan aingura gabeko erlazioak adierazten dituztenez, beste faktore batzuk ere kontuan hartu behar dira. Horietatik garrantzitsuena lexikalizazioa da: - $k$ o sintagma batzuk adjektibo bezala lexikalizatzen dira, hiztunaren hiztegian osorik gordetzen dira eta ez dira momentuan - $k o$ gehituta sortzen. Horrelakoak, eta batez ere, adjektiboek bezala, ezaugarri bat adierazten dutenak, maiz agertzen dira izenaren ostean. Prozesu horrek beste alderdi batzuetan ere eragina du. Lexikalizatu ahala, noizbait adberbio batekin zuzenean lotutako - $k o$ sintagmak independizatzen dira, eta batzuetan haien semantika jatorrizko adberbiotik zertxobait urruntzen da eta, ondorioz, ez da beti konposizionala. Adibidez, etxeko ez da bakarrik 'etxean dagoena'6, eta gogoko edo begiko modukoen esanahia nahiko berezia da. Oinarrizko edo funtsezko bezalakoen kasuan, oinarrian dauden sintagmak gutxiago erabiltzen dira sortutako modifikatzaileak baino. Bestalde, adjektiboen ezaugarriak hartzea nabaria da ere -ko sintagmek konparatibo- eta superlatibo-formak izatean. Adibidez, -ko sintagma batzuek ez dute konparatiboa onartzen (?etxekoagoa; begiratu Euskara Institutua, d.g.), baina beste hainbatekin oso normala da (zentzuzkoago, antzekoago), batez ere gaur egungo hizkuntzan, XIX. mendea baino lehenagoko testuetan adibide asko ez baitaude.

6 Bestalde, -ko duten sintagma batzuk osorik lexikalizatzen dira, hitz elkartuak sortuz: adibidez, etxeko andrea ez da besterik gabe 'etxean bizi den emakume bat' (Azkarate, 1990, 321. orr.). 
Atalaren egitura honakoa da. 3.2.an, - $k o$ modifikatzaileek adierazten dituzten erlazioak (aingura- eta aingura gabekoak) deskribatuko ditut eta erakutsiko dut erlazio horien eta hitz-ordenaren artean lotura dagoela. 3.3.an corpusa zehatzago aztertuko ditut: hasteko Erdi Aroko datuak, Etxepare eta Leizarragaren testuak gero, eta ondoren testuak eremu geografikoetan banatuta. Azkenik, 3.4 atalean, azterketaren ondorio nagusiak bilduko ditut, kontuan hartuz atzizkiaren erabilera-motak eta horien bilakabide diakronikoa.

\subsection{Aingura- eta aingura gabeko erlazioak testuetan}

Azaldu bezala, -ko atzizkiak aingura- eta aingura gabeko erlazioak adieraz ditzake. Corpuseko datuak aztertzean, 2.1. atalean azaldutakoa euskarara ekarrita, ainguraerlazioen adibidetzat hartu dira oinarrian sintagma erreferentziala eta definitua dutenak, edo, beste era batera esanda, - $k o$ sintagmak objektu, denbora edo toki zehatz bati egiten dionean erreferentzia:

(2) bere jauregiko mutil bateki (Ber), carcel gogor onetaco ateac (Laz), lekhu hartako gizonek (Harand), zure sabeleko fruitua (Haranb), Sepulkreko goardak (LeizMat), geure eriozako orduan (Kap), Çure guthun abentuco çazpi garrenecoa (GutErr), gaurko konbersazino kontuzkorik (Mogel), Iaincoaganaco caritatea (Mat)

Aldiz, aingura gabekoaren adibide bezala sailkatu dira oinarria erreferentziala ez duten sintagmak. Kasu horietan, -ko sintagmak ez du balio identifikatzeko, sailkatzeko eta ezaugarritzeko baizik («nolako?», «zer motatako?»):

(3) caleco atea (Land), andikijen maijetako janari gozuak (Mogel), mündüko egitekuetan (Mst), ofrendako ogiak (Harand), parabisuco loria (Mat), promisioko lurrean (Ub), sabeleko miña (Mogel), urtheko kofesioa (Duh)

Testuetako datuek erakusten dute atzizkia gehienetan aingura gabeko erlazioekin erabiltzen dela: 3598 adibidetik \% 69,6tan (zalantzazko adibideak kontuan hartu gabe). Proportzio hori, halere, ez da berbera atzizkiaren erabilera guztietan. Hori zehazteko, gogora dezagun Trasken $(1984,1985,1997)$-ko erlazio-atzizkiaren erabileren sailkapena:

a) -ko flexionala: gaurko, Bilborako, etxeko... Adberbioei edo adberbio-funtzioa duten sintagmei eransten zaie, eta izenen modifikatzaileak sortzen ditu.

b) Izen-multzoa (IM) hartzen duen -ko (Traskentzat «deribazionala», Goenagarentzat -2003- «nolakotasunezko izenlaguna»): hitz gutxiko neska, hamar urteko mutila...). Izen-multzoari eransten zaio, eta izenen modifikatzaileak sortzen ditu (Trask, 1985, 171. orr.).

Trasken sailkapena apur bat garatuz, lan honetan atzizkia lotzen zaion oinarriaren arabera banatu ditut atzizkiaren erabilerak, nire corpusean agertu diren adibideak kontuan hartuz: 
a) Leku-kasuak oinarrian dituzten - $k o$ sintagmak (leku-kasuaren marka agerian dutenak bakarrik): Bilborako, mendietako, nireganako. Soziatiboa dutenak ere multzo horretan sartu ditut, aztertutako testuetan adibide oso gutxi daudelako.

b) Instrumentala oinarrian dutenak (zurezko $)^{7}$.

c) Adberbio-sintagmak oinarrian dituztenak: adberbio sinple (gaurko) eta konplexuak (bitzez hitzeko), partizipio-perpausak (atzo etorritako).

d) Postposizioak oinarrian dituztenak (gatzik gabeko).

e) [izena-ko] motako segidak (mendiko edo fedeko).

f) Izen-multzoa oinarrian dutenak (begi urdineko).

Adberbio-sintagmen gainean eraikiak dira (a)-(d) erabilerak. (e) dela eta, diakronikoki ere adberbio-sintagma genuke horren azpian: Mitxelenak (2011 [1972]) proposatu bezala, inesiboa ezabatuz sor zitekeen erabilera hori. (f)-ren kasuan ere proposa daiteke adberbio-sintagmatik datorrela erabilera hori (begiratu Krajewska, 2017).

Modifikatzaileek adieraz ditzaketen erlazioetara itzulita, aingura gabekoen proportzioaren arabera ordena daitezke atzizkiaren erabilerak (datu zehatzak 3. taulan). Izenmultzokoak beti dira aingura gabeak. Instrumentalaren kasuan, aingura gabeak dira ia beti. Salbuespen oso gutxi daude, adibidez - $z k o$ denbora zehatza adierazten duen - $k o$ atzizkiaren ordez dagoenean (jüdiziozko egünian Mst). Gainerako motetan biak dira posible: aingura-erlazioak zein aingura gabeak. (4)-en [izena + -ko] motaren adibideak ematen dira, eta (5)-en adberbioenak. Aingura erlazioaren proportziorik handiena leku-kasuekin dugu (6).

(4) A: gure animako itxumenak (Gerriko), eriozako pelibururik (Kap) AG: Gorpuzeko, eta arimako reberenziagaz (Kap), neure eriotzako orduan (Olaetx)

(5) A: Gaurko gauaz (Barrutia) AG: gaurko neskatilletati (Mogel)

(6) A: zuen oinetako erhautsa (LeizMat), mundu onetako pena, ta trabaju guztiak (Olaetx), leku hartako gizonek (LeizMat), comarcaetaco arçai guztiaquin (Laz) AG: zeruetako resuma (LeizMat), Ene Aita zeruetakoak (Harand), manera onetako sakrifizioak (Ber), giristino laguna ganako karitatea (Haranb)

7 Instrumentala duten - $k o$ sintagmak bereziak dira, eta ez bakarrik oso ugariak direlako: batzuetan - $z k o-k$ atzizki beregainaren itxura du, eta testu batzuetan adjektiboak sortzeko baliabide nahiko emankorra dela esan daiteke. Leizarragaren itzulpenak horren muturreko adibidea dira: ignorantiazko exkusarik, inperfektionezko relikiak, dibinitate fantasiazko bat, etab. (begiratu Krajewska, 2017, 4.3.4 atala). Leku faltaz, ez dut hemen horretan sakonduko. Datuak aztertzean batzuetan «-zko atzizkiaz» hitz egingo dut, neurri batean azalpenak errazteko, baina baita erlazio-atzizkiaren erabilera horren berezitasunagatik ere. 
3. taula. Aingura- eta aingura gabeko erlazioen proportzioak

\begin{tabular}{|l|c|c|c|}
\hline Mota & Guzt. & AG & A \\
\hline IM & 69 & 100 & 1,5 \\
\hline Instrumentala & 813 & 98,5 & 29,4 \\
\hline Adberbioa & 187 & 70,6 & 39,2 \\
\hline Izena & 2026 & 60,8 & 39,2 \\
\hline Postposizioa & 125 & 60,8 & 47,8 \\
\hline Leku-kasua & 370 & 52,2 & \\
\hline
\end{tabular}

Orain erlazio-motaren eta hitz-ordenaren arteko lotura argitu ahal dugu. Aingura gabeko erlazioak adierazten dituzten - $k$ o sintagmak nahiko maiz -adibideen \% 18,6tanagertzen dira izenaren ostean (4. taula), gehienak izenaren aurrean joan arren. Ainguraerlazioekin, berriz, oso sintagma gutxi doaz izenaren eskuinean, eta salbuespen horiek oso bereziak dira. Gehienak izen propioekin gertatzen dira: San Antonino Florenziakoak (Ber), Aita santu Erromakoak (Kap), Bernard Exeparekoak (Etx), Bethlehem Iudeakoan (Leiz). Aingura gabekoak bezala sailkatu arren, askoren kasuan ez dago batere argi modifikatzailearen funtzioa identifikatzea ala sailkatzea den (adibidez, aposizioaren kasuan -Bethlehem Iudeakoan Leiz-). Gainerako salbuespenak Bizkaiko testuetan aurkitzen ditugu (7), eta baita XVII. mendearen hasierako Erronkariko gutunetan (8).

(7) a. geure ogi egunean eguneangoa, pensamentu egun onetako guztiak (Kap)

b. frutu bedeinquetu zure sabelecoa (VJ)

c. Geure ogi egunean eguneangoa (Arz)

d. mendi albokuetara, sabel beekua (Mogel)

(8) a. Çure azquen gutuna urrietaren oguey eta vorz garrenecoa

b. Çure guthun abentuco çazpi garrenecoa

c. Çure gutun abentuaren emereçu garrenecoa

4. taula. Aingura- eta aingura gabeko erlazioak eta hitz-ordena

\begin{tabular}{|l|c|c|c|}
\hline Erlazioa & Guzt. & IA & IO \\
\hline AG & 2508 & 81,4 & 18,6 \\
\hline A & 1090 & 96,8 & 3,2 \\
\hline
\end{tabular}

Laburbilduz, erlazio-atzizkia gehienetan aingura gabeko erlazioak adierazteko erabiltzen da. Semantikak eragina du hitz-ordenan, aingura erlazioekin -ko sintagmak ez baitira ia inoiz agertzen izenaren eskuinean, baina bai aingura gabekoekin.

\subsection{Testuen azterketa}

Atal honetan lekukotasunak aztertuko ditut, modifikatzaileen kokapenean eragin duten faktoreak hobeto ulertzeko. Erdi Aroko datuekin hasiko naiz. Gainerako ataletan sarreran zehaztu dudan corpuseko datuak aztertuko ditut. 
5. taulak testu bakoitzeko emaitzak aurkezten ditu. Batetik (taularen bigarren zutabean), IOkoen proportzioa eman da - $k o$ sintagma guztiak kontuan hartuta, eta parentesien artean zehaztu da adibide guztien -IAkoen eta IOkoen- kopurua. Hurrengo zutabeetan, IOkoen maiztasuna -ko atzizkiaren erabilera-moten arabera sailkatu da: (1) leku-kasuekin, (2) instrumentalarekin, (3) adberbio eta postposizioekin, (3) izena gehi -ko, eta (5) izenmultzoa hartzen duen -ko. Datu horiek xeheago iruzkinduko ditut hurrengo azpi-ataletan.

5. taula. IOko hitz-ordena eta -ko atzizkiaren motak

\begin{tabular}{|c|c|c|c|c|c|c|}
\hline Testua & Guzt. & Leku-k. & Instr. & Adb. & Izena & IM \\
\hline Lazarraga & $26,8(112)$ & $0,0(9)$ & $0,0(15)$ & $0,0(7)$ & $37,5(80)$ & $0,0(1)$ \\
\hline Landucci & $10,1(89)$ & $0,0(6)$ & $24,0(25)$ & $0,0(1)$ & $5,3(57)$ & \\
\hline Betolatza & $22,7(22)$ & & $14,3(7)$ & $50,0(2)$ & $23,1(13)$ & \\
\hline RS & $4,5(44)$ & $50,0(2)$ & $25,0(4)$ & $0,0(16)$ & $0,0(21)$ & $0,0(1)$ \\
\hline VJ & $41,7(36)$ & $0,0(2)$ & $20,0(5)$ & $0,0(2)$ & $51,9(27)$ & \\
\hline Mikoleta & $35,7(14)$ & $20,0(5)$ & $42,9(7)$ & & $50,0(2)$ & \\
\hline Kapanaga & $25,6(160)$ & $20,0(10)$ & $53,8(26)$ & $42,9(21)$ & $16,0(100)$ & $0,0(3)$ \\
\hline Arzadun & $27,4(73)$ & $0,0(2)$ & $58,3(12)$ & $37,5(8)$ & $19,6(51)$ & \\
\hline Barrutia & $6,3(48)$ & $0,0(5)$ & $0,0(2)$ & $0,0(6)$ & $8,6(35)$ & \\
\hline Olaetxea & $22,4(219)$ & $0,0(13)$ & $71,4(35)$ & $14,8(27)$ & $14,0(143)$ & $0,0(1)$ \\
\hline Mogel & $20,0(95)$ & $0,0(6)$ & $10,0(10)$ & $21,4(14)$ & $9,6(52)$ & $76,9(13)$ \\
\hline Fr Bartolome & $13,4(134)$ & $0,0(17)$ & $26,7(30)$ & $18,2(11)$ & $4,4(68)$ & $62,5(8)$ \\
\hline Otxoa Arin & $28,2(156)$ & $0,0(5)$ & $46,7(45)$ & $25,0(8)$ & $21,4(98)$ & \\
\hline Ubillos & $6,9(159)$ & $0,0(16)$ & $22,9(48)$ & $0,0(22)$ & $0,0(72)$ & $0,0(1)$ \\
\hline Gerriko & $8,4(107)$ & $0,0(7)$ & $31,8(22)$ & $7,7(26)$ & $0,0(52)$ & \\
\hline Etxepare & $13,8(29)$ & $0,0(5)$ & $33,3(6)$ & $0,0(3)$ & $13,3(15)$ & \\
\hline LeizMat & $5,2(192)$ & $1,8(55)$ & $9,5(21)$ & $0,0(11)$ & $5,9(101)$ & $25,0(4)$ \\
\hline LeizABC & $17,5(97)$ & $0,0(23)$ & $46,9(32)$ & $0,0(11)$ & $0,0(29)$ & $100,0(2)$ \\
\hline LeizSarrera & $17,6(108)$ & $0,0(20)$ & $35,4(48)$ & $0,0(5)$ & $3,4(29)$ & $16,7(6)$ \\
\hline Materra & $18,0(172)$ & $0,0(9)$ & $36,6(71)$ & $0,0(18)$ & $5,5(73)$ & $100,0(1)$ \\
\hline Haranburu & $10,3(184)$ & $0,0(19)$ & $47,5(40)$ & $0,0(29)$ & $0,0(95)$ & $0,0(1)$ \\
\hline Haraneder & 8,9 (192) & $11,5(52)$ & $13,3(15)$ & $0,0(11)$ & $5,5(110)$ & $75,0(4)$ \\
\hline Duhalde & $4,2(167)$ & $0,0(13)$ & $11,1(54)$ & $7,1(14)$ & $0,0(79)$ & $0,0(7)$ \\
\hline GutZub & $29,5(44)$ & & $83,3(12)$ & $0,0(4)$ & $10,7(28)$ & \\
\hline Tartas & $1,4(143)$ & $0,0(3)$ & $7,1(14)$ & $0,0(4)$ & $0,8(122)$ & \\
\hline Belapeire & $8,8(137)$ & $0,0(10)$ & $19,2(26)$ & $41,7(12)$ & $1,1(88)$ & $100,0(1)$ \\
\hline Oloroeko kat. & $3,1(96)$ & $0,0(11)$ & $2,4(41)$ & $11,1(9)$ & $2,9(35)$ & \\
\hline Maister & $0,8(132)$ & $0,0(29)$ & $2,6(38)$ & $0,0(6)$ & $0,0(58)$ & $0,0(1)$ \\
\hline Beriain & $20,0(130)$ & $0,0(9)$ & $59,3(27)$ & $0,0(5)$ & $7,3(82)$ & $57,1(7)$ \\
\hline Elizalde & $23,9(46)$ & $0,0(1)$ & $64,3(14)$ & $100,0(1)$ & $3,6(28)$ & $0,0(2)$ \\
\hline Lizarraga & $19,1(115)$ & $0,0(4)$ & $50,0(32)$ & $16,7(6)$ & $6,9(72)$ & $0,0(1)$ \\
\hline Ros & $16,7(18)$ & $0,0(5)$ & & $0,0(2)$ & $27,3(11)$ & \\
\hline Hualde Mayo & $0,5(188)$ & $0,0(14)$ & $2,1(48)$ & $0,0(14)$ & $0,0(103)$ & $0,0(9)$ \\
\hline DoktErr & $7,8(51)$ & $0,0(9)$ & $80,0(5)$ & & $0,0(37)$ & \\
\hline
\end{tabular}




\subsubsection{Erdi Aroa}

Lekukotasunen azterketa Erdi Aroan has dezakegu, garai hartako agirietan jaso ziren lekuen eta pertsona-izenetan -ko sintagma asko aurkitzen baititugu:
(9)
a. Garcia Baçterreco (1227, SJuan) ${ }^{8}$
b. Bazterreco ardançea (1164, Iratxe)

Hitz-hurrenkerari dagokionez, antroponimoetan burua-modifikatzailea da, Salaberri Zaratiegik (2003, 121. orr.) dioen bezala: «Euskal Herriko dokumentazioan toki izengoitiek de preposizioa izan dute erdaraz eta leku genitiboaren hondarkia euskaraz; hau daraman sintagma beti gibelean ezarria dago, inoiz ere ez aitzinean». Erdi Aroko dokumentuetan - $k o$ atzizkia dakarten antroponimoak toponimoak baino ugariagoak dira, baina nahiko datu daude toponimoetan modifikatzaile-buru hurrenkera ohikoagoa zela pentsatzeko, (9)-b-n bezala. Izan ere, (9)-k erakusten duen pertsona- eta leku-izenen arteko oposaketa beste hitz batzuekin ere aurki daiteke (10)-(11). Regueroren (2012) arabera, izen ondoko - ko antroponimoetan aurkitzen da bakarrik.

(10) a. una huerta en el hexido de Urrutico esalde (1482, Cierbide, 1994)
b. Garcia Urrutiquo (1283, Iratxe)
(11) a. iriondoco soroa (TAV, 2.2.4)
b. Semeno Çuarrondocoa (1227, SJuan), iaun Orti Ataondoco (XIII, SJuan)

Salbuespena da Gabarvide Oyanecoa (1284, OEH, s.v. oihan). (12)-b ere salbuespena izan daiteke, mendiko modifikatzailea izenaren ondotik agertzen baita. Hala ere, Mitxelenak (2011 [1953/1973]) azaltzen duenez, kasu horretan - $k o$ atzizkia hipokoristikoa izan daiteke, eta horren itzulpena «el montecillo de...» edo «del monte de...»; oro har, mendiko hitza askotan agertzen da leku- eta pertsona-izenetan, eta beti ez dago garbi - $k o$ atzizkiaren funtzioa zein den. (12)-c-n diminutiboa da ziur aski ( $c f r$. Mendizorrotza), (12)-d, errata ez bada, biak dauzkagu.

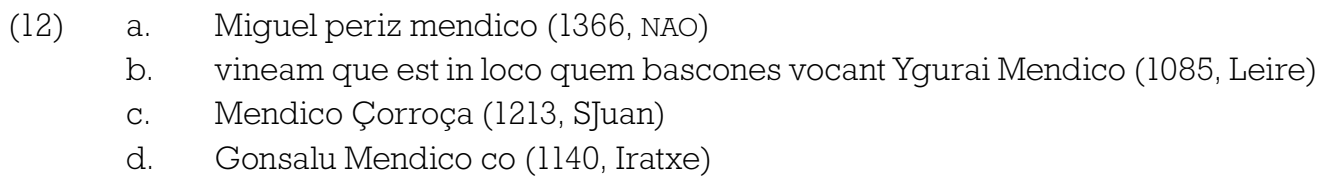

8 Atal honetako adibideak, besterik adierazi ez bada, Reguero Ugarte (2011) lanetik hartu dira. Laburdurak: Iratxe - Colección diplomática de Iratxe, SJuan - Donibane Jerusalengo Ordena, Leire - Leireko monasterioko dokumentuak, NAO - Nafarroako Errege Artxibo Nagusia, Orreaga - Orreagako saroi-zerrenda. 
Aldiz, askotan agertzen diren goiko edo beheko motakoak izenaren aurretik edo atzetik doaz, eta zaila da erabakitzea zein ordena nagusitzen zen (gerora ere ohikoa da modifikatzaile horiek izenaren ostean aurkitzea):

(13) a. el noguedo de Goyco Essea (1258, Iratxe)

b. termino qui dicitur behengo landa (1117, OEH)

c. Johan Peroz Guaraycoecheco (1366, Salaberri Zaratiegi, 2003, 120. orr.)

(14) a. Ezpeleta beerecoa (1284, Orreaga)

b. Urquieguia Beerecoa / Urquieguia Garaycoa (1284, Orreaga)

c. Lander erreca beerecoa / garayacoa (1284, Orreaga)

d. que'l dizen Ossagarte goyticoa (d.g., Irantzu)

Erdi Aroko lekukotasun horiek bi eratara interpreta daitezke. Aukera bat da ondorioztatzea izen osteko kokapena nagusitzen zen, eta izen aurrekoa noizbehinka bakarrik erabiltzen zen. Kopurutan, leku/pertsona bereizketa kontuan hartu gabe, hala da ziur aski dauzkagun datuetan. Baina pentsa dezakegu pertsona-izenetan izen osteko modifikatzaileak aurkitzen ditugu eredu erromantzeari jarraitzen zitzaiolako, edo joera unibertsal-edo bati, genitibo-izen hitz-ordena duten hizkuntza askotan ere abizenak izenaren ondotik baitatoz. Martinez-Aretak (2011, 361. orr.) ere, nahiz eta izen ostekoa zaharra dela aldarrikatu, seinalatzen du arazoa:

Leku genitiboak, beraz, NG-rako joera nabarmenagoa erakusten du. Hala ere, genitibo hau Erdi Aroan ageri den kasu gehienak egitura patronimikoak dira, eta ez dakigu kasuotan zein neurritan jokatzen duen rol bat erromantzeak, edo egituraren izaera semantikoak berak. Izan ere, egitura patronimikoetan jabego genitiboak ere NG hurrenkera agertzen du: Guarcea Ansorena, Sanso Urraquarena (Iratxe, XIII. mendea).

Garai hartako testurik ez dugunez, zaila da auzia erabat argitzea, baina bigarren interpretazioa hobeto ezkontzen da geroko datuekin: leku- eta pertsona-izenen arteko kontrastea Euskara Arkaikoko testuetan aurkitzen dugu eta, azken atalean argudiatuko dudan bezala, oro har, errazagoa da izen ostekoak berrikuntza bezala azaltzea.

\subsubsection{Etxepare}

Etxepareren testuan lau adibidetan aurkitzen dugu erlazio-atzizkia izenaren ostean (15), gainerako 27etan modifikatzailea izenaren aurretik doa (16).

(15) Bernard Exeparekoak, orazione igandeko, erregeren aduokatu bidezko eta nobleari, gizon naturazko

(16) ifernuko garrian, ezkerreko aldetik, haien armadako gizon sendoen balentiak, odolezko izerdi, bekhatuzko amoria, Bihozeko pausuia, gure arteko amoria, egiazko iujia, Garaziko herria...

Bernard Exeparekoak lehen ere ikusi dugun pertsona-izenaren adibidea da. Orazione igandeko izen ondoko adibidetzat hartu arren, ez dago guztiz argi nola interpretatu behar den: - $k o$ atzizkiaren erabilera «arrunta» bezala -'igandean egiten den orazionea'-, 
ala destinatibo bezala - 'orazione igande(ra)ko'. Are gehiago, artikulua falta denez, ezin dugu jakin '[orazione igandeko]' ala '[orazione] [igandeko]' -egitura aposatu bezalaulertu behar den'.

Gainerako bi adibideetan -zko atzizkien konbinazioa dugu: erregeren aduokatu bidezko eta nobleari eta gizon naturazko. Esanahia dela eta, bidezko hitzak Etxeparerenean 'recto, justo' esan nahi du OEHren arabera. Beste testu batzuetan 'justo, legítimo, conforme a derecho; conveniente, correcto' izan ohi da esanahia. Adjektibo lexikalizatua dirudi: bidez adberbioarekin lotura ez da guztiz gardena esanahiari dagokionez. XVI. eta XVII. mendeetako testuetan ere bidezko normalean izenaren atzean kokatzen zen: Leizarragak zazpi aldiz du izen osteko modifikatzaile bezala, eta behin bakarrik izenaren aurretik; Etxeberri Ziburukoak bi aldiz erabili zuen, eta bietan izenaren eskuinean jarrita, eta Haranbururen adibide bakarrak ere izena-modifikatzailea ordena du. Bestalde, izenaren ostean agertzea noble adjektiborekin koordinatuta egoteak ere eragin zezakeen (koordinazioaren adibide gehiago hurrengo atalean emango ditut).

Antzekoa da naturazko-aren kasua. Testuingurua hau da: Ezta gizon naturazko hala egiten duiena. OEHren arabera 'natural, auténtico, como es debido' esan ohi du. Altunak (1980) Etxeparerena 'bien nacido' bezala interpretatzen du. Oinarrian duen naturaz adberbioaren erabilerari begiratzen badiogu, Leizarragak, esaterako, 'izatez, izaeraz' adierazteko baliatu zuen (Ezen naturaz guziak gara maradikatuak, kasu). Handik naturazko sintagmara ('naturala') erraz pasatzen da (iudu naturazkoak dakar Leizarragak, naturazko legea Etxeberri Ziburukoak), baina gainerako adieretan -'behar bezalako' edo 'benetako'- esanahia zertxobait hedatzen edo aldatzen da, Etxepareren adibidean bezala.

\subsubsection{Leizarraga}

Leizarragaren erlazio-atzizkiaren erabilera aztertzeko, hiru testu-zati konparatu ditut: San Mateo, $A B C$ eta Testamentuko paratestuak -Joana Albretekoari eskaintza eta Heuskaldunei-. Horien artean alde batzuk daude testu-generoari dagokionez. San Mateo itzulpena da, eta jatorrizko testuak baldintza zezakeen; gainera, ez denez edozein testuren itzulpena, Bibliarena baizik, erregistro jasoa erabili zuen itzultzaileak. Eskaintza eta Heuskaldunei ez dira itzulpenak, baina, nolanahi ere, oso testu formalak dira. $A B C$, azkenik, bere historiaz asko ez dakigun arren, itzulpena izatekotan, nahiko itzulpen librea izan zitekeen (Salaberri Muñoa, 2014); gainera, haurrei zuzendua zen, eta ez zeukan Bibliaren itzulpenak dakarren ahalik ere fidelena izateko obligaziorik.

9 Errebisatzaile anonimo batek iradokitzen duen bezala, erdaretako baliokideak argigarri izan daitezke horrelako zalantzak argitzeko. Frantsesez eta gaztelaniaz behintzat, testuinguru horretan normalean de preposizioa erabiltzen dela dirudi: prière du dimanche. Horrek, halere, ez du Etxepareren adibidean destinatiboaren interpretazioa guztiz eragozten. 
Hirurak aztertuta, testuen arteko aldeak aurkitu ditut instrumentala dutenen jokaeran, baina ez erlazio-atzizkiaren gainerako motetan: Testamentuan gutxiago agertzen dira izenaren eskuinean instrumentala duten - $k o$ sintagmak. Bestalde, -zko-ren maiztasuna, gainerako - $k o$ motekin konparatuta, ez da bera hiru testuetan: San Mateon 21 aldiz aurkitzen ditugu - $z k o$ duten sintagmak, eta - $k o$ eta - zko guztira 192 aldiz; beraz, adibideen $\% 11 \mathrm{k}$ du $-z k o$. $A B C-\mathrm{n}$ handiagoa da proportzio hori $(32 / 97, \% 33)$, eta paratestuetan handiena $(48 / 108, \% 44)^{10}$.

Instrumentala gehi - $k o$ aparte utzita, IOko - $k o$ gutxi agertzen dira: Testamentuan izenaren eskuinean dago [izena-ko] motakoen \% 6, eta leku-kasua dutenen \% 1,8. Horien artean, aita zeru(eta)ko esamoldea dugu, pertsona-izenak eta pare bat aldiz Bethlehem Iudeako toki-izena:

(17) a. Aita zerukoak (3 aldiz), ene Aita zeruetakoak (LeizTest)

b. Bethlehem Iudeakoan (LeizTest)

c. Antipater Idumeakoaren Seme (LeizSarrera), Iesus Profeta Galilean den Nazareteko (LeizTest)

Aita zeruetako adibideari dagokionez, izenaren ondotik agertzea ez doa atalaren sarreran esandakoaren aurka: leku-kasuek askotan aingura-erlazioak adierazten dituzte, baina ez beti. Horren adibide izan daiteke aita zeruetako: ez du hainbeste adierazten Jainkoa aurkitzen den toki zehatza, bere ezaugarri bat baizik. Bai Aita zeruetako, bai gehiagotan agertzen den Aita zerukoa Bibliako esamoldeen frantsesezko ordaina da mon Père céleste (1563an Genevan argitaratutako edizioan).

Izen-multzoa duten - $k o$ sintagma batzuk ere agertzen dira izenaren atzetik:

(18) Iainko Aita bothere-guzitako, Iainko Aita bothere-guzitakoaren (LeizABC), guzizko exzellentia perfektionetako bat (LeizSarrera), haur bi urthetako eta behereko guziak (LeizTest)

-zko, berriz, askoz ohikoagoa da izenaren ostean: batez ere $A B C-n(\% 47)$ eta Testamentuaren paratestuetan (\% 35). San Mateon, hala ere, -zko, -ko bezalaxe, gehiengehienetan izenaren aurretik doa, bi salbuespenekin: gauza bidezkoa eta Iainkoaren bitza egiazko adibideetan. Beste bi testuetan adibide gehiago daude:

- ardurazko: zenbeit berze ene adiskideren sollizitatze ardurazkoak. Aztertu ez diren testuaren zatietan beste adibide bat ere badu Leizarragak (Ezen tristitia handia, eta tormenta ardurazkoa dudala neure bihotzean), eta behin izenaren aurretik darabil (gure arimen ardurazko etsaiei deabruari, bekatuari, haragiari eta munduari garaitzeko).

$10-z k o$ nahiko gutxi aurkitzen dugu beste testu zahar batzuetan ere: Lazarragarenean eta $R S$-n, esaterako. Litekeena da bere erabilera denborarekin zabaldu izana, eta, gainera, - zko atzizkia neurri batean beregain bihurtzea ere. 
- bidezko: Iainkoaren hira eta mendekio iustoz eta bidezkoz.

- berri on eta dohain onezkoagatik: izen-multzoko -ko sintagmaren antzekoa da, nahiz eta - $z k o$ izan, $-k o$ hutsaren ordez. OEHk «(El, lo) que es para bien» itzulpena ematen du.

- dolorezko, graziazko, gloriazko eta antzekoak ere baditugu (graziazko sei aldiz erabili du IOan eta bitan izenaren aurrean):

(19) a. gordaillu dolorezkoa

b. sekulako izate gloriazkoan, irudi gloriazkoa

c. bere ontasun gratiazkoz, bere miserikordia gratiazkoagatik,

d. gratia mirakuluzkoetarik, haren berthute guzizko exzellenta eta mirakuluzkoa

e. baratze plazentiazkotik

- zelo Iainkoazkoaz: antzekotasuna adierazten duen -zko aurkitzen dugu hor.

- egiazko: izenaren ostean gehien erabiltzen den sintagma da. Hitz hori bietara agertzen da Leizarragarengan, izenaren eskuinean eta ezkerrean. Aztertutako testuetan bi aldaerek maiztasun bera dute (17 IOko eta 15 IAko daude):

(20) a. Iainko egiazkoaren, gure Aita egiazkotan, bere iujemendu iustoz eta egiazkoz, adimendu klaroz eta egiazkoz, Iainkoaren zerbitzu egiazkoa, Iainkoaren zerbitzari egiazkoak

b. egiazko dolurekin, egiazko intellijentia, egiazko deklarazalerik, Iainkoaren egiazko zerbitzuaz, bizitzezko eta egiazko hitza

Nabarmentzea merezi duen beste alderdi bat da -zko duten sintagma asko adjektibo batekin koordinaturik doazela: iustoz eta egiazkoz, klaroz eta egiazkoz, exzellenta eta mirakuluzkoa. Gerta daiteke beste adjektibo bat egoteak zerikusia izatea -zko sintagmen kokapenarekin: biak izenaren alde berean jarri nahi badira, aukera bakarra da erlazio-atzizkia duena adjektibo arrunt bezala erabiltzea, kontrakoa -adjektiboa izenaren ezkerrean jartzea- ezinezkoa baita euskaraz (salbuespen gutxi batzuekin, nazioak adierazten dituzten adjektiboekin, esaterako). Bat aurrean eta bestea atzean jartzeak ez dirudi ezinezkoa, baina Leizarragarenean behintzat zaila da aurkitzen. Bestalde, segur aski adjektiboranzko aldaketaren seinaletzat ere har daiteke hori (kategoria bereko sintagmak koordinatu baitatezke).

Laburbilduz, Leizarragaren testuetan IOko posizioan gehien agertzen dira -zko eta izen-multzoko modifikatzaileak. Leku-kasuak eta [izena-ko] salbuespen gutxi batzuekin izenaren aurretik doaz (eta salbuespen nahiko bereziak dira: Aita zeru(eta)koa eta bitan pertsona-izenetan). Adberbioek eta postposizioek IAko kokapena dute beti.

\subsubsection{Araba}

Landucciren hiztegian aukera guztiak aurkitzen ditugu - $k o$ atzizkiarekin: gehienak izenaren aurretik doaz (21), baina kontrako ordenaren adibide batzuk ere badaude (22). 
Gainera, - $k o$ sintagmak izen determinatuari aposaturik ere agertzen dira (23). Izen ostekoen maiztasuna nahiko handia da: \% 10 (aposatuak kontuan hartu gabe). Atzizkiaren bi erabilera bakarrik agertzen dira izenaren eskuinean: instrumentalarena (\% 24) eta [izena-ko] (\% 5).

(21) a. yssasoco almirantea, Santiagoco videa, ardaotaco picheroa...

b. burniazco gauçea, azerozco ballestea, çerazco blandoea, suzco votoya, sedasco capulloa, caracolezco escalera, burrniazco ylçea, narruzco correoa, espatasco ysgrimea, çerazco entorcha, jaquinezco guaçea, canasco jocuac, miracuruzko gauçea, miracuruzco gauçea, soldatazco mutila, soldatazco nescatoa, vidriozco erredom[e]a

(22) a. ancora ysasoco, cardenale erromacoa, gauça çerucoa, gauça esquecoa, arraunça corrincoa

b. çapata ylariscoa, andra ysçegozcoa, costilla ezpinazocoa, cota mallazcoa, chapea metalezco[a], gauça pisu guchisco[a]

(23) esquadrea guerracoa, axcorea egurretacoa, croçea epizticoana, muçuac surretacoac, popea navioco[a], hostua ele]ga[xacoa

Lazarragak -zko oso gutxitan erabiltzen du: eskuizkribu osoan 15 agerraldi bakarrik daude, eta atzizkia duen sintagma izenaren aurrean doa salbuespenik gabe:

(24) amorezco erregue jauna, amoriozco erregue jauna, asecabazco salsea, dicha onezco semea, enojuzco verva oec, erdeeraazco ipui batec, erregalozco tendaric, muguer-arrizco bioça, concenciazco traturic, listra onezco dardoa, malla finezco cotea, seda finozco calcea, tafetaezco benda bategaz, urregorrizco tablaetan, urregorrizco letra baçugaz

Bitan instrumentala duen izen-multzoko modifikatzailearen motakoak ditugu, onezko adjektiboarekin (dicha onezco semea). Antzeko sintagmek izenaren ostean agertzeko joera dute beste hainbat testutan, baina hemen aurretik doaz.

Instrumentala duen aldaera ez bezala, [izena-ko] motakoak askotan agertzen dira izenaren ostean, eta nahiko maiztasun handiarekin: 30 adibidetik \% 38tan. Adibideak banan-banan aztertuta, hala ere, izen osteko - $k o$ atzizkiaren erabilera oso mugatua dela ohartzen gara:

(25) Larrosa maiacecoa, Ene laztan biozeqoa, ardao çuri San Martingoa, Belagai Butroecoa, Gaztelu Guebaracoan, Joan Lopez jauna Çuaçuco, Jaun Cerucoa (24 aldiz)

Gehien erabili dena Jaun Cerucoa da, nahiz eta kontrako ordenaren adibideak ere egon: bitan Ceruetaco Jaunari, sei aldiz Ceruco Jaunac, eta behin, beste testuinguru batean, ceruco irargui çuria. Lau adibideetan toponimoak agertzen dira. Egituraren nolabaiteko emankortasunaren adierazgarri izan daitezke Larrosa maiacecoa (testuan behin mayaceco lora ederraena ere bada) eta Ene laztan biozeqoa adibideak. 
Orokorrean, beraz, esan daiteke Lazarragaren testuan izen aurreko egitura nagusitzen dela, eta izen ostekoa nahiko murriztua dela. Harrigarri samarra da -zko izenaren aurretik erabiltzea beti.

Betolatzak 22 adibide ditu guztira, eta bost dira izen ostekoak, adberbioarekin bat, - zko bat eta gainerakoak izenekin:

(26) biziza betikoan, artikulu fedekoak, Paskua Erresurreziñokoetan, erri negarrezko onetan, eguzari guardetakoetan

Bai betiko, bai fedeko -ko sintagmak gero askotan agertuko dira testuetan, eta askotan IOan. Azken adibidea -eguzari guardetakoetan-, halere, nahiko bitxia da, nominalizatutako aditzekin ez baita oso ohikoa izen osteko hitz-hurrenkera, nahiz eta izen-sintagma bezala nominalizazioek ez duten ezer berezirik.

Instrumentalarekin -ko zazpi aldiz agertzen da testuan -guztiak erlijio-hiztegiarekin lotuak-, eta erri negarrezko onetan da izen ondoko egituraren adibide bakarra. Gainerakoak hauek dira: entendimentuzgo doea, fortalezazko doea, konsejuzko doea, luxuriazko pekatuetan, miserikodiasko amea, sabiduriazgo doea. Azkenik, Betolatzak egitura aposatuaren adibide bakan batzuk ditu: mandamentuak Iaun goikoaren legekoak, areriak arimakoak edo sentiduak gorpuzekoak. Halere, guztiak testuinguru berean agertzen dira: atalaren hasieran, zerrenda bat baino lehen, Sentiduak gorpuzekoak dira bost edo Areriak arimakoak dira iru.

Oro har, beraz, erlazio-atzizkiaren hiru klase agertzen dira IOko posizioan Arabako testuetan (6. taula): gehien izenekin eta instrumentalarekin (Lazarragarengan izan ezik), eta behin beti adberbioarekin.

6. taula. Izen osteko - ko sintagmen proportzioak Araban

\begin{tabular}{|l|c|c|c|}
\hline Mota & Guzt. & IA & IO \\
\hline Izena & 147 & 75,5 & 24,5 \\
\hline Adberbioa & 7 & 85,7 & 14,3 \\
\hline Instrumentala & 46 & 84,8 & 15,2 \\
\hline Leku-kasua & 13 & 100 & 0 \\
\hline Postposizioa & 3 & 100 & 0 \\
\hline IM & 1 & 100 & 0 \\
\hline
\end{tabular}

\subsubsection{Bizkaia}

Bizkaiko eta Gipuzkoako testu zaharrenetan Erdi Aroko dokumentuetan ikusi dugun fenomeno bera errepikatzen da: pertsona-izenetan - $k o$ atzizkia izenaren atzetik doa (Milia Lasturco), baina bestela (izen arruntetan edo leku-izenetan) gehienetan izenaren aurretik (Lastur-co torre gorea), salbuespen batzuk dauden arren (oñeztar barruangoac, ardao Madrigalgoa): 
(27) a. Milia Lasturco, Marina Arraçolaco, andra Maria Balda-co, andra Ojanda Gabiola-co (Milia Lasturko, TAV, 3.1.5)

b. Lastur-co torre gorea

(28) a. jaun Peru Abendañococ (Pedro Abendañokoaren kantua, TAV, 3.1.6)

b. gorpuceco lau araguioc

c. Aramaioco contrara

(29) a. oñeztar barruangoac (Arrasateko erreketa, TAV, 3.1.7)

b. cantoeco çarçayqueran

c. Oçaetaco jaun gazteac

(30) ardao Madrigalgoa (Sandailia, TAV, 3.1.10)

(31) Jaun Diaoz Arocoa (TAV, 3.1.14)

$R S$-en izen aurrekoa nagusitzen da (32), eta 44 adibideetatik bi bakarrik dira izen ostekoak (\% 4,5): bat adlatibo-destinatiboarekin, aingura gabeko erlazioa adieraziz, çaldi çelaracoa (el caballo para silla); bestea instrumentalarekin, hurte erurrezco.

(32) balizco oleac, betico ytoguinac, hurte gustico oguia, ygazco lapurroc, ypirdico puza, gorpuz guztico mina...

Oro har, - $k o$ instrumentalarekin oso gutxitan agertzen da; bost adibide daude testuan eta horietatik bat izen ostekoa:

(33) a. lastozco buztana, amucozco buztana, hurrezco atea

b. hurte erurrezcoa, garizcoa

XVII. mendean, - $k o$ sintagmak izenaren eskuinean askoz maizago agertzen dira. VJn \% 40 inguru IOkoak dira, Mikoletaren elkarrizketetan heren bat eta Kapanagaren dotrinan laurden bat. XVIII. mendean, testu gehienetan gutxi gorabehera adibideen $\% 20$ IOkoak dira. Salbuespena Barrutia da: \% 6 ditu bakarrik. XIX. mendean maiztasuna zertxobait jaisten bada ere, IOko - ko sintagmak ez dira guztiz desagertzen.

7. taula. Izen osteko -ko sintagmen proportzioak Bizkaian (parentesien artean adibideen kopurua zehaztu da, IAkoak eta IOkoak batera)

\begin{tabular}{|l|l|l|l|l|}
\hline Mota & \multicolumn{1}{|c|}{ RS } & XVII & XVIII & XIX \\
\hline Izena & $0,0(21)$ & $24,0(129)$ & $14,4(229)$ & $6,7(120)$ \\
\hline Adberbioa & $0,0(6)$ & $7,7(13)$ & $21,2(33)$ & $5,9(17)$ \\
\hline Leku-kasua & $50,0(2)$ & $18,8(16)$ & $0,0(18)$ & $0,0(23)$ \\
\hline Postposizioa & $0,0(10)$ & $72,7(11)$ & $0,0(9)$ & $50,0(8)$ \\
\hline Instrumentala & $25,0(4)$ & $47,4(38)$ & $65,3(49)$ & $22,5(40)$ \\
\hline IM & & $0,0(3)$ & $0,0(1)$ & $71,4(21)$ \\
\hline
\end{tabular}

[izena-ko] motari dagokionez, XVII. mendean adibide guztien laurdenak daude izenaren ostean, \% 15 XVIII. mendean eta \% 7 bakarrik XIX.enean (7. taula). (34)-n ikus daitekeen bezala, adibide asko (edo gehienak) erlijio-hiztegikoak dira. XVIII. mendean 
Arzadunek eta Olaetxeak ere erabiltzen dituzte. XIX. mendean gutxiago dira (baina aztertutako testuak ez dira dotrinak).

(34) a. Kapanaga: voto castidadecoa, exerçiçio Virtutecoacaz, Sacramêtu penitenciacoan, Neure Angueru Goardacoa, Ayta sâtu Eromacoac, escubitur ezquerrecoan, beste persona elexacoac gati, vme familiacoacaz, Mandamentu elexacoac, Espiritu zeruco baçuc, Sacramentu comuniocoa

b. Mikoleta: persona sospechacoa

c. VJ: vssu erracoacora, Acto Contricinoecoa, Acto Fedecoa, Esperanzacoa eta Caridedecoa, Virtute Caridedecoa, Virtute Esperanzacoa, Obra Misericordiecoac, misterio Santissime Trinidadecoa, Encarnacinoecoa, Eriozacoa, Passinoecoa, Mandamientu Iangoicoen leguecoac, frutu bedeinquetu zure sabelecoa, Mandamientu Iangoicoen leguecoac eta Ama Elexa Santacoac, Santissimu Sacramentu altaraco, Ama Elexa Santacoac

d. Arzadun: akto kontrizinokoa, berba konsagrazinokoak, Sakramentu Santu Eukaristiakoan

e. Olaetxea: Sakramentu Santu Ordeakoa, bere akto kontrizinoekoa, Sakramentu Santu Oleaziñoekoa, Sakramentu Santu Penitenziakoa, pena Sentidukoa, pena Dañukoa, Sakramentu Santu Penitenziakoa, examiña konzienziakoa

IOko modifikatzaile askok instrumentala dute, (35)-(36). Testu askotan IOen proportziorik handiena dute horiek: adibidez, Kapanagaren -zko adjektiboen erdiak IOkoak dira, eta Olaetxearen \% 70. Egiazko, gaztelaniazko verdadero adjektiboaren ordaina, agertzen da gehien. Kapanagak, adibidez, bederatzi aldiz darabil, eta behin bakarrik izenaren aurrean ${ }^{11}$. Olaetxeak eta Arzadunek inoiz ez daukate egiazko izenaren aurrean. Sintagma asko bi eratara agertzen dira, Kapanagarengan adibidez miserikordiazko lau aldiz izenaren ondoan dugu, eta bitan aurrean.

a. Kapanaga: coroêa arançazcoa, eguiazco (premia eguiazcoagaz, premia eguiazcoagaz, Iaungoico eguiazcoen...), obra misericordiazcoac, estatu graçiazcoan

11 Bidenabar, gaztelaniaz ere verdadero adjektiboaren izenarekiko kokapena aldakorra da, Kapanagaren dotrina elebiduneko adibide hauek erakusten duten moduan: hombre verdadero - guiçon eguiazcoa, verdadera necesidad - Premia eguiazcoagaz, La verdadera penitencia - Penitencia eguiazcoa. Hizkuntza erromantzeetan adjektiboak izen aurrekoak eta izen ostekoak izan daitezke (Salvi, 2016): gehienetan kokapen bakoitza esanahi jakin batekin dago lotuta (normalean, izenaren ostekoek identifikazioaren funtzioa dute, eta aurrekoek ezaugarri bat ematen dute), eta adjektibo guztiak ezin dira bietara agertu. Askotan, halere, zaila da gaia aztertzea; Jensenek (1994, 42. orr.), esaterako, okzitanierari buruz hau dio: «La place de l'adjectif épithète par rapport au substantif qu'il modifie es essentiellement un problème d'ordre stylistique ou rythmique qui ne se prête pas à une analyse grammaticale». Latinez biak posible baziren ere, izen aurrekoa, oro har, ohikoagoa zen, baina aldatzen joan zen preferentzia hori, latin arruntean izen osteko adjektiboen maiztasuna igotzen baita (Lapesa, 2000 [1975]). Gaztelaniaz (Martínez, 2006) adjektiboa bi kokapenetan agertzen da, baina maiztasuna aldatu egin da: XVII. mendetik aurrera izen osteko posizioa indartzen doa (XIII. mendean adjektiboa-izena adibideen \% 60tan erabiltzen zen, eta XXI.ean \% 81tan). Agian gaztelanian jazo ziren aldaketa horiek euskaran nolabaiteko eragina izan zuten. Gai horretan -euskaraz eta hizkuntza erromantzeetako adjektiboekin gertatzen dena konparatzea- sakontzea mereziko luke. 
b. Mikoleta: pare bi fraca miesascoac, lau alcandora euren ydun lechuguillascoacas, fraca terciopelo acuchilladuscoac

c. VJ: Obra virtutescoac eta honac

(36) a. Olaetxea: egiazko (IO 13, IA 0), graziazko (IO 4, IA 0), Jangoikozko (IO 1), mirarizko (IO 2), miserikordiazko (IO 5, IA 0)

b. Arzadun: egiazko (IO 6), miserikordiazko (IO l, IA l)

Izen-multzoaren gainean eraikitako adibide gehien XIX. mendean aurkitu ditut, eta gehienak izenaren ostean doaz. XVII. eta XVIII. mendeetakoak, aldiz, izenaren aurrean daude kokatuta. Adibide batzuetan izen-multzokoa beste adjektibo batekin koordinatuta agertzen da: gizon baldres, zantar, aziera txarrekuentzat (Mogel), gizon prestu ta biotz onekua (Mogel) edo dantza desonestubagorik ta lotsa gitxiagokorik (frBart).

Testu batzuetan IOko adberbioen proportzioak handia badirudi ere, betiko adberbioa da horrela erabiltzen den ia bakarra (urreko da bigarrena).

Kapanagak bako postposizioa duten modifikatzaileak izenaren ostean jartzen ditu askotan: misericordia fin bacoagan, podere finbacoagan, desseo ordea baco bat iaateco, eta edateco. Gaztelaniaz infinito eta desordenado agertzen dira hiru adibide horietan: misericordia ynfinita, en poder ynfinito eta Apetito desordenado â comer y beuer. Gutxiago erabiltzen du kontra posizio horretan: codiziac honestidaden contracoac, eta aziendenac edo codizia, eta desseo Iustizien contracoac, edo modu guestocoac. XIX. mendean ere agertzen dira halakoak: emakume ezkondu bagakuak (frBart), arima bildurti ta gatz bagako bat (Mogel), beso kaltebagako ori (Mogel), atso arima bagako txar onek (Mogel).

Leku-kasuak dituzten modifikatzaileei dagokienez, oso adibide gutxitan doaz izenaren ostean:

señale ateticoacaz (Kap, por señales exteriores), neure pensamentu egû onetaco guztiac (Kap), gueure ogui egunean eguneangoa (Kap), dozena erdi bocader surretacoac (Mikol), geure ogi egunean eguneangoa (Arz)

Oro har, aingura-erlazioa adierazten duten IOko - $k$ o sintagmen oso adibide gutxi aurkitzen baitira, eta guztiak Bizkaiko testuetan, (7) adibideak, hemen errepikatuta, erakusten duen moduan:

(38) a. geure ogi egunean eguneangoa, pensamentu egun onetako guztiak (Kap)

b. frutu bedeinquetu zure sabelecoa (VJ)

c. Geure ogi egunean eguneangoa (Arz)

d. mendi albokuetara, sabel beekua (Mogel)

Beraz, Bizkaiko testuetan IOko modifikatzaileen maiztasuna oso altua izateaz gain, gainerako eremuekin konparatuta, zabalduena ere bada, aingura erlazioetara hedatzen hasia baitzen. 


\subsubsection{Gipuzkoa}

8. taulan ikus daitekeen bezala, instrumentala duten -ko sintagmak izenen ostean erabiltzen dira gehien Gipuzkoako XVIII. eta XIX. mendeetako testuetan: Otxoa Arinen testuan \% 47 dira IOkoak, Ubillosenean \% 23, eta Gerrikorenean \% 32.

Berriro ere izenaren eskuinean egiazko da ohikoena; beste batzuk dira hauek: arrazoizko (OA, Gerriko), dudazko (OA), gezurrezko (Ubill) eta graziazko (OA), ekarraizko (Ubill, Lege naturala edo ekarraizkoa), jaungoikozko (Gerriko, 'divino') eta miserikordiazko (OA). Egiazko eta gezurrezko izenaren aurrean ere aurki daitezke (bigarrena maizago izenaren ezkerrean).

8. taula. Izen osteko - $k o$ sintagmen proportzioak Gipuzkoan (parentesien artean adibideen kopurua zehaztu da, IAkoak eta IOkoak batera)

\begin{tabular}{|l|c|c|}
\hline Mota & XVIII & XIX \\
\hline Izena & $12,4(170)$ & $0,0(52)$ \\
\hline Adberbioa & $4,5(22)$ & $9,1(22)$ \\
\hline Leku-kasua & $0,0(21)$ & $0,0(7)$ \\
\hline Postposizioa & $12,5(8)$ & $0,0(4)$ \\
\hline Instrumentala & $45,1(71)$ & $31,8(22)$ \\
\hline IM & $0,0(1)$ & \\
\hline
\end{tabular}

[izena-ko] motari dagokionez, Bizkaian ikusi ditugunen antzekoak dira IOak; hau da, gehienak erlijio-hiztegiari lotuak. Guztiak Otxoa Arinen testuan aurkitu ditut, Ubillosek eta Gerrikok halakoak izenaren aurrean jartzen baitituzte beti:

(39) Sakramentu Baptisteriokoa, bizitza tenporako onetan, Akto Esperantzakoa, Sakramentu Eukaristiakoa, Akto Fedekoa, Sakramentu Konfesiokoak, beste itz dibina konsagrazioko aen birtutez, Akto kontriziokoa, Aita Santu Romakoa $(\mathrm{OA})$

Postposizio eta adberbioen artean, izenaren ostean aurkitzen ditugu bage (OA, bizitza fin bageko artan), sekulako (OA, pena sekulakoa), betiko (Gerriko) eta burko (Gerriko).

\subsubsection{Lapurdi}

Lapurdin izen ostean ohikoenak dira instrumentalaren eta izen-multzoaren (40) gainean egindako - $k o$ sintagmak (9. taula).

(40) gizon fede aphurretakoak (Harand), gizon fede gutitakoa (Harand), seme bat bere iduritaco (Mat)

XVII. mendeko datuak eta Leizarragarenak nahiko antzekoak dira, baina XVIII-XIX. mendeetan IOkoen maiztasuna jaisten da. 
Instrumentala duten modifikatzaileen artean, izenaren ostean maizenik egiazko, fedezko eta miserikordiazko aurkitzen ditugu. Gainerakoak behin edo bitan baino ez dira agertzen aztertutako testuetan:

(41) a. Materra: presuna baquezcoac (2 aldiz), obra verthutezcoac, eguiazco (9), Articulu fedezcoac (10), misericordiazco (5)

b. Haranburu: Gauza bidezko guzietan, zeure bulhar birginazkoan, Gure Iainko botherezkoak, egiazkoa (2), Iaun espantuzkoa, esperanza zinezko bat, Artikulu fedezkoak, ○ Birjina loriazkoa!, oren izigarrizko hartan, miserikordiazkoa (5), geure ezteustasunaren aithorzeko agudezia neurrizkoa, bekhatore ondikozkoa, andre pietatezkoa, Zirkunzisione dolorezkoaren

c. Haraneder: bestimenda kamelu illezkoa, karga pisuak eta ezin jasanezkoak

d. Duhalde: egiazko (2), sentimendu Jainkozkoak, bizitzerik Jainkoskoena, joko sobraniazko, afekzione ta estekamendu sobraniazkorik

9. taula. Izen osteko - ko sintagmen proportzioak Lapurdin (parentesien artean adibideen kopurua zehaztu da, IAkoak eta IOkoak batera)

\begin{tabular}{|l|l|l|l|l|}
\hline Mota & Leiz & XVII & XVIII & XIX \\
\hline Izena & $4,4(159)$ & $2,4(168)$ & $2,4(110)$ & $0,0(78)$ \\
\hline Adberbioa & $0,0(11)$ & $0,0(21)$ & $0,0(7)$ & $0,0(1)$ \\
\hline Leku-kasua & $1,0(98)$ & $0,0(28)$ & $11,5(52)$ & $0,0(13)$ \\
\hline Postposizioa & $0,0(16)$ & $0,0(26)$ & $0,0(4)$ & $7,7(13)$ \\
\hline Instrumentala & $33,7(101)$ & $40,5(111)$ & $13,3(15)$ & $11,1(54)$ \\
\hline IM & $40,0(10)$ & $50,0(2)$ & $75,0(4)$ & $0,0(7)$ \\
\hline
\end{tabular}

Leku-kasua dutenak gehien-gehienetan izenaren aurrean joaten dira, zeruetako edo zerutikako (biak Haranederrenak) kenduta. Beste hizkeretako hainbat testutan -eta Leizarragarengan- azaltzen den zeruko hitza Materrak du bakarrik Lapurdin (aita cerucoaren seme bakoitça eta Iainco aita cerucoari). [izena-ko] egituran atzizkia oso gutxitan agertzen da izenaren eskuinean: aipatu den aita zerukoa esapidean eta toki-izenetan, batik bat (adibidez, Bethlehem Iudeakoan Leiz). Duhalderen testuan kanpo postposizioa behin agertzen da izenaren atzetik: bertze denbora-iragaitz premiaz kanpokoetarik.

\subsubsection{Nafarroa Garaia}

Nafarroa Garaian ere - $z k o$ da izenaren eskuinean gehien aurkitzen dugun modifikatzaile-mota, eta nahiko maiztasun handiarekin, -zko duten sintagma guztien erdiak izenaren eskuinean baitaude (10. taula). Ohikoenak berriro ere egiazko, fedezko eta miserikoardiazko dira:

(42) a. Beriain: libru debozioskoak, pasio doloreskoa, heriotze doloreskoa, egiaskoa (10 aldiz), itzak konsagraziokoak, obra miserikordiaskoak, Salmoak Penitenziaskoak

b. Elizalde: Artikulo Fedeskoak (5), zeure begi miserikordiasko oiek, Obra Miserikordiaskoak (3) 
c. Lizarraga: leku inmundiziaskoan, ogi ordioskoa, eguraldi on bakeskoak, zur earreskoa, egiaskoa (8), gorputz aragiskoa, idolo arriskoak ta metaleskoak, lagun gaixtoen gaitz kutsusko abasto, kontxa urreskoan

10. taula. Izen osteko - $k o$ sintagmen proportzioak Nafarroa Garaian (parentesien artean adibideen kopurua zehaztu da, IAkoak eta IOkoak batera)

\begin{tabular}{|l|c|c|}
\hline Mota & XVII & XVIII \\
\hline Izena & $7,3(82)$ & $6,3(95)$ \\
\hline Adberbioa & $0,0(4)$ & $33,3(7)$ \\
\hline Leku-kasua & $0,0(9)$ & $0,0(5)$ \\
\hline Instrumentala & $59,3(27)$ & $54,3(46)$ \\
\hline IM & $66,7(6)$ & $0,0(2)$ \\
\hline
\end{tabular}

[izena-ko] mota dela eta, noizean behin agertzen da izenaren ostean, baina maiztasuna ez da handia (\% 6-7). Hauek dira adibideak:

(43) a. Beriain: tenpestade dilubioko andihura, Eliza sandu Erromakoak, itzak konsagraziokoak, Martirolojio Erromakoaren, San Antonino Florenziakoak, Erregia Portugalekoa

b. Lizarraga: pobreza biotzekoareki, aren ondasun etxeko ta kanpoko guziak, korona gloriakoa, bere Aingeru guardiakoa, argitasun zeruko bat admiragarria

Izen-multzoen eta adberbioen gainean egindako - $k o$ sintagmak ere batzuetan izenaren ostean doaz (IMkoak, hala ere, Beriainek bakarrik ditu eskuineko posizioan), nahiz eta horien maiztasuna, oro har, ez den oso handia:

(44) a. bizize sekulakoa (Elizalde), beraren Birjinidade garbi betirokoa (Lizarg)

b. gauza inportanzia anditakoak (Ber), gauza lastima anditakoa (Ber)

\subsubsection{Zuberoa}

Zuberoan, oro har, - $k o$ modifikatzaileak nahiko gutxi agertzen dira izenaren ostean (11. taula). XVII. mendean aurkitzen ditugu gehien, batez ere Etxarten gutunetan (\% 30); gainerako testuetan askoz gutxiago daude: Belapeirek \% 9 ditu, eta Tartasek \% 1,5 bakarrik.

11. taula. Izen osteko - $k o$ sintagmen proportzioak Zuberoan (parentesien artean adibideen kopurua zehaztu da, IAkoak eta IOkoak batera)

\begin{tabular}{|l|c|c|c|}
\hline Mota & Etxart & XVII (2. erdia) & XVIII \\
\hline Izena & $10,7(28)$ & $1,0(209)$ & $1,1(93)$ \\
\hline Adberbioa & & $41,7(12)$ & $9,1(11)$ \\
\hline Leku-kasua & & $0,0(13)$ & $0,0(40)$ \\
\hline Postposizioa & $0,0(4)$ & $0,0(4)$ & $0,0(4)$ \\
\hline Instrumentala & $83,3(12)$ & $15,0(40)$ & $2,5(79)$ \\
\hline IM & $40,0(10)$ & $100,0(1)$ & $0,0(1)$ \\
\hline
\end{tabular}


Izenaren ostean gehienetan doaz - zko sintagmak eta betiere adberbiotik eratorritako modifikatzailea. Etxarten 1616ko gutunetan 12 aldiz agertzen da -zko, eta bi aldiz bakarrik izenaren aurrean: bi berce baquezco personnequi eta graciazco ourthiaren. Izenaren ostean, aldiz, egiazko eta bidezko aurkitzen ditugu. IOkoen adibide guztiak hauek dira:

(45) a. Etxart: arcordu bidescoric eta eguiascoric, iaun eguiascoa eta bidescoa, accordu eguiascoric, eguia eta leguia eguiascoa, baque osso eta eguiasco baten, arcordu eta baque eguiascoric, repos eguiasco baten

b. Belapeire: Jinko egiazko, kristi egiazkoaren, saintü egiazkoez, obra miserikordiazkoak, Birjina saintiaren misterio dohatsü, alagera, edo penazko zonbaitetan

c. Tartas: aita familiazkoa

XVIII. mendean maiztasuna jaisten da. Oloroeko katiximan -ko sintagmen \% 3 bakarrik doa izenaren eskuinean (gayça importanciazco çonbaytetan, spiritu bethiereco, Andredana Maria martchocouan), eta Maisterrenean \% 1 baino ez (adibide bat: libertate egiazkorik).

\subsubsection{Erronkaribar}

1616ko Zuberoa eta Erronkari arteko gutunetan izen osteko - $k o$ atzizkiaren adibide batzuk aurkitzen ditugu Rosek idatzitakoetan (12. taula). Guztiak [izena-ko] motakoak dira; bitan leku-izenekin eta hirutan datak ematean:

(45) a. gobernadore jaunari eta abbade Santa Engraçiacoari

b. Agustin Martin Uztarrozecoac

c. Çure azquen gutuna urrietaren oguey eta vorz garrenecoa

d. Çure guthun abentuco çazpi garrenecoa

e. $\quad$ Çure gutun abentuaren emereçu garrenecoa

Interesgarria da gutunetan -zko bat ere ez aurkitzea, ez izenaren aurretik, ez ondotik.

12. taula. Izen osteko -ko sintagmen proportzioak Erronkaribarren (parentesien artean adibideen kopurua zehaztu da, IAkoak eta IOkoak batera)

\begin{tabular}{|l|c|c|}
\hline Mota & Ros & XIX \\
\hline Izena & $27,3(11)$ & $0,0(140)$ \\
\hline Adberbioa & & $0,0(14)$ \\
\hline Leku-kasua & $0,0(5)$ & $0,0(23)$ \\
\hline Postposizioa & $0,0(2)$ & \\
\hline Instrumentala & & $9,4(53)$ \\
\hline IM & & $0,0(9)$ \\
\hline
\end{tabular}

Geroko Erronkaribarko testuetan (Hualde Mayo eta Doctrina Christiaia) -zko bakarrik agertzen da izenaren ostean, eta oso noizbehinka: ein deuri cidarrezco (Hualde), Articulo fedezcoac (DoktErr) eta medrachu ilavete conzecionezcoac (DoktErr). 


\subsection{Orokortuz}

Atal honetan bilduko ditut testuen azterketaren emaitza nagusiak.

Oro har, IOko - $k o$ sintagmen maiztasun txikiena ekialdeko testuetan aurkitu dut (Zuberoan \% 6, Erronkaribarren \% 3, 13. taula), eta handiena mendebaldekoetan eta Nafarroakoetan (\% 20 inguru). Azken eremu horietan IOko ordena luzaroago mantendu da (15. taula): XVIII. eta XIX. mendean Iparraldeko testuetan oso gutxi agertzen zen, Hegoaldekoetan, aldiz, nahiko maiz.

Motaz mota begiratuta (13. eta 14. taulak), izen-multzoa eta instrumentala duten modifikatzaileak maizenik azaltzen dira modifikatzen duten izenaren ondotik (adibide guztien \% 40 eta \% 31, hurrenez hurren). Gutxien, aldiz, leku-kasuen gainean egindakoak: \% 3,5 bakarrik. Beraz, IOko ordena ohikoena da aingura gabeko erlazioak ohikoenak diren mota berberetan: izen-multzoaren eta instrumentalaren gainean eraikitako sintagmetan. Eta kontrara, gutxien agertzen da aingura-erlazioak gehien adierazten dituzten leku-kasuekin egindako -ko sintagmetan.

13. taula. -ko atzizkiaren izen osteko erabilera: eremuen arteko aldeak (adberbioak eta postposizioak batera eman dira; parentesien artean adibideen kopurua zehazten da, IAkoak eta IOkoak batera)

\begin{tabular}{|l|l|l|l|l|l|l|}
\hline Eremua & \multicolumn{1}{|c|}{ Guztiak } & \multicolumn{1}{|c|}{ Leku-k. } & \multicolumn{1}{|c|}{ Instr. } & \multicolumn{1}{c|}{ Adb. } & \multicolumn{1}{c|}{ Izena } & \multicolumn{1}{c|}{ IM } \\
\hline Araba & $19,7(223)$ & $0,0(15)$ & $14,9(47)$ & $10,0(10)$ & $24,0(150)$ & $0,0(1)$ \\
\hline Bizkaia & $20,9(823)$ & $6,7(60)$ & $45,8(131)$ & $19,6(107)$ & $14,4(499)$ & $57,7(26)$ \\
\hline Gipuzkoa & $15,2(422)$ & $0,0(28)$ & $33,9(115)$ & $7,1(56)$ & $9,5(222)$ & $0,0(1)$ \\
\hline Nafarroa & $20,3(291)$ & $0,0(14)$ & $56,2(73)$ & $18,2(11)$ & $6,6(182)$ & $40,0(10)$ \\
\hline Erronkaribar & $3,1(257)$ & $0,0(28)$ & $9,4(53)$ & $0,0(16)$ & $2,0(151)$ & $0,0(9)$ \\
\hline Lapurdi & $10,8(1112)$ & $3,7(191)$ & $31,0(281)$ & $1,0(99)$ & $3,3(516)$ & $32,0(25)$ \\
\hline Nafarroa Beherea & $13,8(29)$ & $0,0(5)$ & $33,3(6)$ & $0,0(3)$ & $13,3(15)$ & \\
\hline Zuberoa & $5,6(552)$ & $0,0(53)$ & $13,7(131)$ & $17,1(35)$ & $1,8(331)$ & $50,0(2)$ \\
\hline
\end{tabular}

14. taula. -ko atzizkiaren motaren eta hitz-ordenaren arteko erlazioa. Erlazio-atzizki mota bakoitzeko, IAkoen eta IOkoen proportzioak eman dira

\begin{tabular}{|l|c|c|c|}
\hline Mota & Guzt. & IA & IO \\
\hline IM & 69 & 59,4 & 40,6 \\
\hline Instrumentala & 814 & 68,2 & 31,8 \\
\hline Postposizioa & 127 & 89 & 11 \\
\hline Adberbioa & 203 & 90,6 & 9,4 \\
\hline Izena & 2055 & 91,8 & 8,2 \\
\hline Leku-kasua & 398 & 96,5 & 3,5 \\
\hline
\end{tabular}


15. taula. IOko -ko sintagmen proportzioak Ipar eta Hego EH. Parentesien artean adibideen kopurua eman da (IAkoak eta IOkoak batera)

\begin{tabular}{|l|c|c|}
\hline Mendea & Ipar EH & Hego EH \\
\hline XVI & $11,8(423)$ & $17,7(260)$ \\
\hline XVII (1. erdia) & $15,8(400)$ & $20,3(128)$ \\
\hline XVII (2. erdia) & $5,0(279)$ & $29,0(210)$ \\
\hline XVIII & $5,0(420)$ & $20,3(787)$ \\
\hline XIX & $4,2(166)$ & $13,7(336)$ \\
\hline
\end{tabular}

[izena-ko] mota dela eta, Arabako eta Bizkaiko -batez ere XVII-XVIII. mendeetakotestuetan IOko -ko sintagmen adibide gehien aurkitu dut (Arabako testuetan \% 24, Bizkaikoetan \% 14). Oro har, ikusi dugun bezala, erlijioarekin lotutako hiztegian dira ohikoen.

Izen-multzoa hartzen duten -ko sintagmek izenaren eskuinean agertzeko joera dute. Adibide gehien Bizkaiko eta Lapurdiko testuetan bildu dira, eta IOkoen proportzioa oso handia da (\% 57 eta \% 32, hurrenez hurren).

Postposizioa duten - $k o$ sintagmei dagokienez, eskuineko posizioan gehienetan gabe/ bage eta (gutxiago) kontra agertzen dira. Bizkaiko eta Gipuzkoako testuetan bakarrik aurkitu dut. Salbuespena Duhalderen adibide bat da.

Adberbioen gainean egindako - $k$ o modifikatzaileek izenaren aurretik agertzeko joera dute. Hala ere, betiko, betiereko eta sekulako hitzak askotan izenaren ondoan jartzen dira, batez ere Bizkaiko, Arabako, Nafarroako eta Zuberoako testuetan.

Erlazio-atzizkia leku-kasuei lotzen zaienean, oso gutxitan kokatzen da izenaren eskuinean: corpusean aurkitutako adibide gehienetan zeruetako edo zerutikako erabili da, Jainkoari erreferentzia eginez.

Instrumentala duten - $k o$ sintagmak askotan dira izen ostekoak. Maiztasun txikiena Erronkaribarko eta Zuberoako testuetan aurkitu dut. Handiena Nafarroako testuetan dugu: adibideen erdiak inguru daude izenaren eskuinean. Bizkaian eta Araban ere askotan izenaren ostean doaz modifikatzaile horiek (testu gehienetan \% 20-60). Lapurdin XVI. eta XVII. mendeetan ere handi samarra da proportzioa: \% 30-40, salbuespena Leizarragaren San Mateo da. Halere, gero jaisten da: Haranederrek \% 13 du, eta Duhaldek \% 11. Zuberoako eta Erronkaribarko egileek, salbuespen gutxi batzuekin, izenaren aurretik kokatzen dituzte (baina Etxarten gutunetan kontrakoa gertatzen da).

Dagoeneko aipatu bezala, -ko sintagma batzuk lexikalizatu direla dirudi. Orain arte esandakoa osatzeko, testuetan gehien agertzen diren modifikatzaile batzuk aztertuko ditut zehatzago.

Maiztasun handiena egiazko-k du: nik aztertutako testuetan 213 adibide agertzen dira (konparatzeko, hurrengoak -miserikordiazko-k- 44 agerraldi ditu bakarrik). 
Adjektibo erabat lexikalizatuta dirudi. Datu gehiago lortzeko, $K G$-n aztertu dut modifikatzaile horren erabilera. Hego EHko testuetan IOkoen proportzioak handiagoak dira Ipar EHkoetan baino: Hegoaldeko testu gehienetan adibideen erdiak baino gehiago doaz izenaren ostean; Iparraldekoetan, normalean, \% 20-30 (16. taula). Nolanahi ere, Iparraldeko testu zahar batzuetan nahiko maiz agertzen da izenaren eskuinean: Leizarragaren testuetan \% 48, Materrarenean \% 48, Belapeirerenean \% 52 eta Etxeberri Ziburukoarenean $\% 70^{12}$.

16. taula. Egiazko modifikatzailearen erabilera: IOkoen proportzioak $K G$-n XVI-XIX. mendeetako Hego eta Ipar EHko testuetan

\begin{tabular}{|l|l|c|c|}
\hline Eremua & Mendea & Guzt. & IO (\%) \\
\hline Hego EH & XVII (1. erdia) & 1 & 100 \\
\cline { 2 - 4 } & XVII (2. erdia) & 6 & 100 \\
\cline { 2 - 4 } & XVIII (2. erdia) & 352 & 50,9 \\
\cline { 2 - 4 } & XIX (1. erdia) & 362 & 81,8 \\
\cline { 2 - 4 } & XIX (2. erdia) & 308 & 80,2 \\
\hline \multirow{5}{*}{ Ipar EH } & XVI & 138 & 47,8 \\
\cline { 2 - 4 } & XVII (1. erdia) & 68 & 38,2 \\
\cline { 2 - 4 } & XVII (2. erdia) & 162 & 24,7 \\
\cline { 2 - 4 } & XVIII (1. erdia) & 123 & 35,8 \\
\cline { 2 - 4 } & XVIII (2. erdia) & 184 & 29,9 \\
\cline { 2 - 4 } & XIX (1. erdia) & 55 & 16,4 \\
\cline { 2 - 4 } & XIX (2. erdia) & 392 & 32,1 \\
\hline
\end{tabular}

Erlazio-atzizkia duten modifikatzaile batzuk maizago agertzen dira izenaren eskuinean; beste batzuk, aldiz, oso gutxitan. Modifikatzaile batzuen lexikalizazioaren seinaletzat har daiteke hori. Maiz erabiltzen diren -zko modifikatzaileen artean, hauek dute IOkoak izateko joera: egiazko, miserikordiazko, fedezko edo graziazko, baina ez, esaterako, haragizko edo gezurrezko hitzek (17. taulan adibide gehiago eta datu zehatzak eman dira).

Atzizkiaren gainerako motei begiratuta (18. taula), hitz askotatik eratorritakoak beti agertzen dira izenaren aurretik. Adibide bat mundu lemapean bildu direnak dira (munduko, mundu honetako, etab.): 128 agerraldi dituzte guztira, eta beti doaz izenaren ezkerrean (neurri batean aingura erlazioak adierazten dituztelako askotan). Gauza bera gertatzen da infernu, lur edo heriotza lemekin. Aldiz, beti(ere) adberbiotik, gabe postposiziotik edo fede, altare edo zeru izenetik sortutakoak noizean behin izenaren ostean aurkitzen ditugu (nahiz eta, -zko sintagmekin konparatuta, IOkoen maiztasuna txikiagoa izan). 
Aztertutako moten artean, beraz, adjektiboranzko aldaketa nabarmenena da instrumentalaren gainean egindako - $k o$ sintagmetan. Halere, hitz-ordenaren aldaketa kategoria osoan baino gehiago modifikatzaile jakin batzuekin gertatu dela esan daiteke: kokapenean, semantikaz gain (aingura vs aingura-gabe), lexikalizazioak du eragina ${ }^{13}$.

17. taula. Gehien erabiltzen diren - $z$ ko modifikatzaileak eta hitz-ordena ${ }^{14}$

\begin{tabular}{|l|c|c|c|c|}
\hline Lema & Guzt. & Testuak & IA & IO \\
\hline bide & 7 & 6 & 14,3 & 85,7 \\
\hline grazia & 19 & 7 & 31,6 & 68,4 \\
\hline miserikordia & 44 & 13 & 31,8 & 61,4 \\
\hline egia & 213 & 23 & 47,2 & 55,4 \\
\hline fede & 36 & 7 & 42,9 & 52,8 \\
\hline arrazoi & 14 & 3 & 81,3 & 28,6 \\
\hline jainko & 16 & 4 & 85,7 & 18,8 \\
\hline zilar & 7 & 1 & 87,5 & 14,3 \\
\hline negar & 8 & 8 & 90,9 & 12,5 \\
\hline penitentzia & 11 & 7 & 91,7 & 9,1 \\
\hline debozio & 12 & 5 & 91,7 & 8,3 \\
\hline gezur & 12 & 2 & 84,6 & 8,3 \\
\hline amorio & 13 & 7 & 96,9 & 7,7 \\
\hline haragia & 32 & 8 & 100 & 3,1 \\
\hline su & 12 & 7 & 100 & 0 \\
\hline borondate & 9 & 5 & 100 & 0 \\
\hline egunero & 9 & 8 & 100 & 0 \\
\hline euskara & 9 & 4 & 100 & 0 \\
\hline burdina & 7 & 100 & 0 \\
\hline bihotz & & & 0 \\
\hline
\end{tabular}

13 Errebisatzaile anonimo batek iradokitzen du modifikatzailearen konplexutasun sintaktikoak eta pisu fonologikoak izenarekiko kokapenarekin zerikusia izan dezaketela, eta - $k o$ sintagma luzeagoek eta konplexuagoek izenaren eskuinean agertzeko joera handiagoa dutela. Hemen aztertu dudan corpusean behintzat ez dirudi faktore horiek semantika eta lexikalizazioa bezain garrantzitsuak direnik. Ausaz aukeratutako 200 izen aurreko eta 200 izen osteko modifikatzaile aztertuta, 88k bakarrik dute hitz bat baino gehiago, eta horietako 57 izen aurrekoak dira. Bestalde, corpusean aurkitutako erlatibo jokatugabeak, nahiko modifikatzaile konplexuak, izen aurrekoak dira guztiak (nahiz eta izen ostekoak lekukotzen diren; begiratu Krajewska, 2017, 2.4. atala).

14 Testuetan agertzen diren - zko duen modifikatzaile bakoitzari lema «estandarizatua» esleitu zaio, hitzen aldaera ezberdinak batera aztertu ahal izateko. -zko atzizkiarekin agertzen den lema bakoitzeko IAkoen eta IOkoen proportzioak eman dira (ehunekotan). Bestalde, bakoitzaren agerraldi-kopurua corpusean eta «testuak» zutabean zenbat testutan aurkitu diren adierazi da. 
18. taula. Gehien erabiltzen diren - $k o$ sintagmak eta hitz-ordena (-zko dutenak izan ezik $)^{15}$

\begin{tabular}{|c|c|c|c|c|}
\hline Lema & Guzt. & Testuak & IA & $\mathrm{IO}$ \\
\hline betiere & 23 & 5 & 69,6 & 30,4 \\
\hline fede & 38 & 11 & 71,1 & 28,9 \\
\hline gabe & 38 & 13 & 71,1 & 28,9 \\
\hline beti & 39 & 7 & 82,1 & 17,9 \\
\hline altare & 33 & 13 & 84,8 & 15,2 \\
\hline zeru & 308 & 27 & 86,4 & 13,6 \\
\hline lege & 31 & 11 & 87,1 & 12,9 \\
\hline kontra & 24 & 8 & 91,7 & 8,3 \\
\hline egun & 55 & 22 & 92,7 & 7,3 \\
\hline sekula & 30 & 11 & 93,3 & 6,7 \\
\hline etxe & 32 & 14 & 93,8 & 6,3 \\
\hline bihotz & 51 & 14 & 94,1 & 5,9 \\
\hline eliza & 106 & 19 & 94,3 & 5,7 \\
\hline eskuin & 35 & 12 & 94,3 & 5,7 \\
\hline sabel & 23 & 13 & 95,7 & 4,3 \\
\hline kanpo & 26 & 10 & 96,2 & 3,8 \\
\hline mundu & 128 & 24 & 100 & 0 \\
\hline infernu & 57 & 19 & 100 & 0 \\
\hline lur & 48 & 14 & 100 & 0 \\
\hline heriotza & 44 & 14 & 100 & 0 \\
\hline trinitate & 40 & 10 & 100 & 0 \\
\hline juizio & 38 & 14 & 100 & 0 \\
\hline herri & 32 & 10 & 100 & 0 \\
\hline gorputz & 31 & 14 & 100 & 0 \\
\hline arima & 26 & 12 & 100 & 0 \\
\hline paradisu & 23 & 10 & 100 & 0 \\
\hline aitzin & 21 & 11 & 100 & 0 \\
\hline
\end{tabular}

\section{ONDORIOAK}

Lan honetan saiatu naiz erakusten erlazio-atzizkiak sortzen dituen modifikatzaileen kokapenean hainbat faktorek eragiten dutela.

15 Testuetan agertzen den - $k o$ sintagma bakoitzari lema «estandarizatua» esleitu zaio, hitzen aldaera ezberdinak batera aztertu ahal izateko. - $k o$ atzizkiarekin agertzen den lema bakoitzeko IAkoen eta IOkoen proportzioak eman dira (ehunekotan). Bestalde, bakoitzaren agerraldi-kopurua corpusean eta «testuak» zutabean zenbat testutan aurkitu diren adierazi da. 
Semantika garrantzitsua da: adierazten dena aingura gabeko erlazioa bada, litekeena da izenaren eskuinean erabiltzea, aingura-erlazioekin, salbuespen bakan batzuekin, ez da hori gertatzen.

Bestalde, hitz-ordenari begira, atzizkiaren erabilera-moten artean badaude diferentzia diakronikoak: instrumentalaren eta izen-multzoaren gainean egindakoak lehen testuetarako ohikoak ziren izenaren eskuinean. Gainerakoak geroago hedatzen direla dirudi. XVI. mendeko testuetan, hauek agertzen zaizkigu izenaren ondoan: pertsonaizenak (Bernard Exeparekoak), zeruko, zeruetako motakoak (Aita zeruetakoa) eta -zko lexikalizatu batzuk (egiazko, bidezko). Ondoko mendeetan izen osteko erabilera hedatuagoa dirudi, baina ohikoenak instrumentalaren eta izen-multzoaren gainean eraikitakoak ziren, artean ere. Mendebaldeko hizkeretan izen osteko [izena + -ko] motakoak asko agertzen dira, batez ere erlijioarekin lotutako hiztegian.

Hala ere, -ko sintagma guztiek, semantikaren eta formaren aldetik antzekoak izanda ere, ez dute berdin jokatzen, batzuek joera handiagoa baitute izenaren ostean joateko. Lexikalizazioaren adierazle da hori: adjektibo tipikoen ezaugarri batzuk hartzen dituzte - $k o$ sintagma batzuek, eta, azkenean, beste edozein adjektibo bezala hasten dira erabiltzen, baita hitz-ordenari dagokionez ere.

Azkenik, hizkeren arteko aldeak ere baditugu: oro har, zenbat eta ekialderago, orduan eta izen osteko - ko sintagma gutxiago, bai maiztasunari begira, bai izen osteko egituraren emankortasunari begira.

Erlazio-atzizkian hizkuntza erromantzeen nolabaiteko eragina ikus daiteke: ez horrenbeste modifikatzailearen kokapenean, baizik eta - $k o$ sintagmen ugaritasunean Eragin hori batzuetan izan zitekeen zuzena (hau da, alboko hizkuntzetan genitiboak eta adjektiboak normalean izenaren eskuinean doazelako), baina agian inportanteagoa zen zeharkako eragina: batez ere itzulpenetan, - $k o$ atzizkia (askotan -zko) modu oso hedatua da hizkuntzan falta diren adjektiboak euskaratzeko. Honela azal daiteke prozesua: demagun testu baten idazleak celeste adjektiboa behar zuela, eta zeruko erabiltzea erabaki zuela. Arazo bat sortu ahal zitzaion: hitz hori non jarri, izenaren ezkerrean --ko sintagma bat delako- ala eskuinean -behar zuena adjektibo bat zelako-.

IOko - $k$ o sintagmak agertzen dira dagoeneko testu zaharrenetan, eta lehenago, Erdi Aroko pertsona-izen batzuetan. Galdera da, beraz, zein den zaharragoa. Ez da erabat ezinezkoa izen osteko ordena zaharragoa izatea, baina zaila litzateke azaltzea zergatik sortu zen beste hurrenkera. Aldiz, izen aurreko posiziotik abiatzen bagara, ez da oso konplikatua azaltzea nola hasi ziren - $k o$ sintagma batzuk izenaren osteko kokagunean jartzen: adjektiboekiko analogiaz, edo, zehatzago esanda, -ko sintagma adjektibo prototipiko bezala hartuta. Izenen modifikatzaileen eta adjektiboen ezaugarriak kontuan hartuta, aldaketa naturala da, jabetza-modifikazio eskalaren elkarren ondoan kokatuta baitaude, 2.2. atalean ikusi dugun moduan.

Hitz-ordenaren aldaketa hori, halere, ez zen erabat burutu: gehien instrumentala duten - $k o$ sintagmekin, baina horiekin ere ez guztiz, eta gainera badirudi atzera egin 
duela: XVIII. mendean oraindik oso ohikoak ziren izen osteko -ko sintagmak, baina gaur egun izenaren aurretik erabiltzeko joera nagusitzen ari da. Antzekoa -baina agian zertxobait lehenago- gertatu zen izen osteko erlatiboekin (Krajewska, 2016): asko aurkitzen ditugu testu zaharretan, baina hizkera gutxi batzuetan bakarrik gorde dira eta horietan ere gutxi erabiltzen dira.

Egin daitekeen galdera da, beraz, zerk eragin zuen izenaren eskuineko modifikatzaileak oro har, eta - $k o$ sintagmak bereziki, baztertzea. Egitura horiek -eskuinean dauden erlatiboak eta - $k o$ sintagmak- berrikuntzak badira, proposatzen dudan bezala, zerbaitengatik ez dute arrakastarik izan. Azterketa sakonagoa beste lan baterako utzi behar, baina bi azalpen -agian elkarren osagarri- aipa daitezke. Bata, estrukturala da. Modifikatzaileentzako bi aukera izatea -izen aurrekoa eta izen ostekoa- ez da oso ekonomikoa, eta izen aurrekoak zerbaitengatik abantaila zuen. Agian egitura horiek ez ziren ondo ezkontzen hizkuntzaren gramatikarekin, eta horren arrazoi bat izan daiteke sintagmen buruak azken posizioan izateko euskarak duen joera ${ }^{16}$. Beste azalpen posible bat, errazen erlatiboetara aplika daitekeena, hizkuntzaren gaineko kontzientziarekin dago lotuta, edo ustez erromantzeen eraginez sortutako egiturak gaitzesteko eta saihesteko joerarekin. Hori batez ere hizkuntza idatzitik desagertzearen arrazoia izan zitekeen, baina ez da ezinezkoa horrelako ideiek eragin zabalagoa izatea ere.

\section{ERREFERENTZIAK}

Altuna, P. (1980). Linguae vasconum primitiae (edizio kritikoa). Bilbo: Mensajero \& Euskaltzaindia.

Azkarate, M. (1990). Hitz elkartuak euskaraz. Bilbo: Deustuko Unibertsitatea.

Azkarate, M. \& Altuna, P. (1992). -ko/-dun atzizkiez. In Luis Villasanteri omenaldia (91-111. orr.). Bilbo: Euskaltzaindia. (Iker, 6).

Bilbao, G., Gómez, R., Lakarra, J., Manterola, J., Mounole, C., \& Urgell, B. (prestatzen). Gabriel Echart zuberotarraren eta Miguel Ros erronkariarraren arteko gutuneria (1615-1617).

Bilbao, G., Gómez, R., Lakarra, J., Manterola, J., Mounole, C., \& Urgell, B. (2010). Lazarraga eskuizkribua: edizioa eta azterketa (1.0). Vitoria-Gasteiz: UPV/ EHU. Hemendik hartua: http://www.lazarraga.com

Cierbide, R. (1994). Toponimia Alavesa: Apeo de Vitoria y su jurisdicción de 14811486. ASJU, 28(2), 543-568.

De Rijk, R. P. G. (1998 [1993]). Basque hospitality and the suffix -ko. In De lingua vasconum: selected writings (377-389. orr.). Bilbo: UPV/EHU. (ASJU-ren Gehigarriak, 43).

De Rijk, R. P. G. (2008). Standard Basque: a progressive grammar. Cambridge, Massachusetts: MIT Press.

16 Ohikoa da objektu-aditza ordena duten hizkuntzek izena-erlatiboa ordena izatea, baina gutxi dira izenagenitiboa duten objektu-aditza hizkuntzak. Halere, -ko atzizkia genitibo bezala hartzea ez da nahitaez oso zuzena. 
Eguzkitza, A. (1993). Adnominals in the grammar of Basque. In J. I. Hualde \& J. Ortiz de Urbina (arg.), Generative Studies in Basque Linguistics (163-188. orr.). Amsterdam: John Benjamins.

Euskara Institutua. (d. g.). Izenlagunak eta izenondoak. In Sareko Euskal Gramatika (SEG). Hemendik hartua: www.ehu.eus/seg

Goenaga, P. (1981). Ohizko euskal sintaxia eta sintaxi berria. In A. Tovar (arg.), Euskal linguistika eta literatura: bide berriak (139-161. orr.). Bilbo: Deustuko Unibertsitatea.

Goenaga, P. (1985). Gramatika bideetan. Erein: Donostia.

Goenaga, P. (2003). -en eta -ko atzizkiez berriro. In Euskal gramatikari eta literaturari buruzko jardunaldiak XXI. mendearen atarian (I-II) (279-303. orr.). Bilbo: Euskaltzaindia.

Jensen, F. (1994). Syntaxe de l'ancien occitan. Tübingen: Max Niemeyer.

Koptjevskaja-Tamm, M. (2002). Adnominal possession in the European languages: form and function. STUF-Language Typology and Universals, 55(2), 141172.

Koptjevskaja-Tamm, M. (2004). Maria's ring of gold: Adnominal possession and non-anchoring relations in European languages. In J. Kim, Y. A. Lander, \& B. H. Partee (arg.), Possessives and beyond: semantics and syntax (155181. orr.). Amherst: GLSA Publications.

Krajewska, D. (2016). Euskarazko erlatiboen diakroniaz: testu zaharren azterketa. FLV, 122, 223-248.

Krajewska, D. (2017). Euskararen sintaxi diakronikorantz. Doktore tesia, UPV/EHU. doi: 10.13140/RG.2.2.18154.62405.

Krajewska, D., Zuloaga, E., Ariztimuño, B. Santazilia, E., Uribe-Etxebarria, O., \& Reguero, U. (2016). Esteve Materraren Do(c)trina Christiana (1617 \& 1623): edizioa eta azterketa. Vitoria-Gasteiz \& Bilbo: UPV/EHU \& Euskaltzaindia.

Kuryłowicz, J. (1964). The inflectional categories of Indo-European. Heidelberg: C. Winter.

Lafon, R. (1999 [1965]). Les deux génitifs en basque. In J. Haritschelhar \& P. Charritton (arg.), Vasconiana (173-197. orr.). Bilbo: Euskaltzaindia.

Lakarra, J. A. (1996). Refranes y sentencias (1596): ikerketak eta edizioa. Bilbo: Euskaltzaindia.

Lakarra, J. A. (2005). Prolegómenos a la reconstrucción de segundo grado y al análisis del cambio tipológico en (proto)vasco. Palaeohispanica, 5, 407-470.

Lapesa, R. (2000 [1975]). La colocación del calificativo atributivo en español. In Estudios de morfosintaxis histórica del español (210-234. orr.). Madril: Gredos.

Magni, E. (2013). Synchronic gradience and language change in Latin genitive constructions. In A. Giacalone Ramat, C. Mauri \& P. Molinelli (arg.), Synchrony and diachrony. A dynamic interface (177-199. orr.). Amsterdam \& Philadelphia: John Benjamins.

Martínez, A. (2006). La frase adjetiva. El orden del sustantivo y el adjetivo. In C. Company Company (arg.), Sintaxis histórica de la lengua española, 2: La frase nominal (1223-1320. orr.). Mexiko: FCE, UNAM.

Martínez-Areta, M. (2011). Euskararen hitz hurrenkeraren garaikaketa baterako materialak. Oihenart, 26, 343-379. 
Mitxelena, K. (2011). Obras completas. J. A. Lakarra \& I. Ruiz Arzalluz (arg.), Donostia \& Gasteiz: «Julio Urkixo» Euskal Filologia Mintegia, Gipuzkoako Foru Aldundia, UPV/EHUko Argitalpen Zerbitzua. I-XV. liburukiak.

Mitxelena, K. (2011 [1953/1973]). Apellidos vascos. In Mitxelena (2011), IX. liburukia (1-235. orr.).

Mitxelena, K. (2011 [1958]). N. Landuchio, Dictionarium linguae Cantabricae (1562). In Mitxelena (2011), XII. liburukia (199-363. orr.).

Mitxelena, K. (2011 [1964]). Textos arcaicos vascos. In Mitxelena (2011), XII. liburukia (1-171. orr.).

Mitxelena, K. (2011 [1972]). Etimología y transformación. In Mitxelena (2011), VII. liburukia (93-107. orr.).

Nikolaeva, I. and Spencer, A. (2010). The Possession-Modification Scale: A universal of nominal morphosyntax. Lan argitaragabea. Hemendik hartua: https:// www.researchgate.net/publication/253508645_The_Possession-Modification_Scale_A_Universal_of_Nominal_Morphosyntax

Odriozola Pereira, J. C. \& Cantero Gutiérrez, A. (1992). Euskal izenondoaren kokapenari buruzko zenbait ohar. Euskera, 37(2), 1035-1048.

Padilla-Moyano, M. (prestatzen). Oloroeko katixima: edizioa eta azterketa.

Pagola, R. M., Iribar, J. J., \& Iribar, I. (arg.). (1997). Bonaparte ondareko eskuizkribuak: erronkariera. Bilbo: Universidad de Deusto.

Reguero Ugarte, U. (2011). Erdi Aroko euskararen corpusa osatzeko ekarpena. ASJU, 45(2), 153-233.

Reguero Ugarte, U. (2012). Erdi Aroko Euskara: dialektalizazioaren hastapenetarantz. Master tesia, UPV/EHU.

Reguero Ugarte, U. (2013). Word order. In M. Martínez-Areta (arg.), Basque and proto-Basque. Language-internal and typological approaches to linguistic reconstruction, (429-460. orr.). Frankfurt am Main: Peter Lang.

Salaberri Muñoa, P. (2014). Leizarragaren idazlanetan barrena. Bilbo: UPV/EHUko Argitalpen Zerbitzua.

Salaberri Zaratiegi, P. (2003). Euskal deiturategia: patronimia. Bilbo: Udako Euskal Unibertsitatea.

Salvi, G. (2016). Word order. In A. Ledgeway \& M. Maiden (arg.), The Oxford guide to the Romance languages (997-1011. orr.). Oxford: Oxford University Press.

$T A V=$ Mitxelena, K. (2011 [1964]).

Trask, R. L. (1984). Synchronic and diachronic studies in the grammar of Basque. Doktore tesia, School of Oriental and African Studies (University of London).

Trask, R. L. (1985). -ko atzizkia euskaraz. Euskera, 30(1), 165-173.

Trask, R. L. (1997). The history of Basque. Londres: Routledge.

Trask, R. L. (2003). The noun phrase: nouns, determiners and modifiers; pronouns and names. In J. I. Hualde \& J. Ortiz de Urbina (arg.), A grammar of Basque (113-170. orr.). Berlin: Mouton de Gruyter.

Ulibarri Orueta, K. (2010). Viva Jesus dotrina: edizioa eta azterketa. ASJU, 44(2), 41154.

Zabala, I. (1999). Izen-sintagma konplexuak: adjektiboen eta izenlagunen segidak. In J. C. Odriozola (arg.), Zenbait gai euskara teknikoaren inguruan (107157. orr.). Bilbo: UPV/EHUko Argitalpen Zerbitzua. 